\title{
WestVirginiaUniversity
}

THE RESEARCH REPOSITORY @ WVU

Graduate Theses, Dissertations, and Problem Reports

2018

\section{Roofing Practices and Fall Prevention in the Construction Industry}

Hadi A. Shishtar

hashishtar@mix.wvu.edu

Follow this and additional works at: https://researchrepository.wvu.edu/etd

Part of the Civil Engineering Commons, and the Construction Engineering and Management Commons

\section{Recommended Citation}

Shishtar, Hadi A., "Roofing Practices and Fall Prevention in the Construction Industry" (2018). Graduate Theses, Dissertations, and Problem Reports. 3731.

https://researchrepository.wvu.edu/etd/3731

This Problem/Project Report is protected by copyright and/or related rights. It has been brought to you by the The Research Repository @WVU with permission from the rights-holder(s). You are free to use this Problem/Project Report in any way that is permitted by the copyright and related rights legislation that applies to your use. For other uses you must obtain permission from the rights-holder(s) directly, unless additional rights are indicated by a Creative Commons license in the record and/ or on the work itself. This Problem/Project Report has been accepted for inclusion in WVU Graduate Theses, Dissertations, and Problem Reports collection by an authorized administrator of The Research Repository @ WVU. For more information, please contact researchrepository@mail.wvu.edu. 


\title{
ROOFING PRACTICES AND FALL PREVENTION IN THE CONSTRUCTION INDUSTRY
}

\author{
Hadi Shishtar \\ Problem Statement Report submitted to the Statler College of Engineering and \\ Mineral Resources \\ at West Virginia University \\ in partial fulfillment of the requirements \\ for the degree of \\ Master of Science \\ in \\ Civil and Environmental Engineering \\ Yoojung Yoon, Ph.D., Chair \\ Radhey Sharma, Ph.D., Co-Chair \\ P.V. Vijay, Ph.D., P.E., Committee Member \\ Department of Civil and Environmental Engineering \\ Morgantown, West Virginia \\ 2018
}

Keywords: Roofing Practices, Roof Types, Roofing Materials, Roof Slope and Pitch 


\section{Abstract \\ ROOFING PRACTICES AND FALL PREVENTION IN THE CONSTRUCTION INDUSTRY}

\section{Hadi Shishtar}

Roofing is an important profession in the construction industry yet there is a lack of understanding of its safeness. It is generally believed that roofing is an occupation that can be easily practiced by anyone. However, there are many key factors that are associated with roofing, which may impact the lives of roofers who often face major risks at work. According to the Occupational Safety and Health Administration (OSHA), roofing is one of the leading causes of falling deaths among construction workers. The Bureau of labor statistics has reported that roofers are highly exposed to nonfatal injuries. They have also revealed that roofers had the highest fatality rates among construction workers in 2015 and 2016. There are many factors that lead to roofer's falls such as the structural slope of rooftops, the type of roofing materials used, and failure to comply with constructional safety guidelines of lifting tools and personal fall arrest systems. With the help of laws and regulations implemented by OSHA, along with the field research conducted by the National Institute for Occupational Safety and Health, employers can now strive to maintain the safety of workers and reduce fatal injuries and deaths. This research explores the practices involved in roofing and how roofing contributes both positively and negatively to the safety of roofers. It also discusses the effectiveness of regulations implemented by OSHA. As a result, this research provides recommendations for the roofing practices and regulations that can potentially assist roofers in creating a safe working environment. 


\section{ACKNOWLEDGMENTS}

I am deeply grateful and indebted to many people whom made this project possible. First of all, I would like to thank my Master's committee chair and co-chair, Dr. Yoojung Yoon and Dr. Radhey Sharma, for giving me the opportunity to work on this interesting project, and for their guidance, advice, and valuable feedback. I want to also thank Dr. P.V. Vijay for serving as a third examining member on my committee and assisting in the structure analysis aspect of this project. My appreciation is also extended to Dr. Gary Winn, Mr. John Hyman, and Ms. Jennifer Fuller for providing essential information on the safety management component of this work. I would like to also acknowledge the Kuwaiti Embassy for sponsoring my Master's studies and allowing me to pursue my passion in research. Last but not least, my sincere gratitude goes to my parents and siblings for their continuous support and unconditional love. They are an indispensable support system of mine which I will value and cherish forever. 


\section{Table of Content}

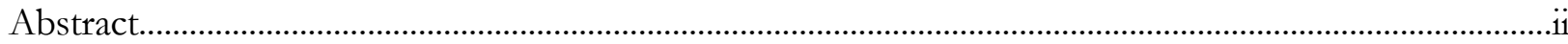

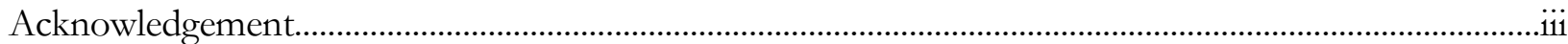

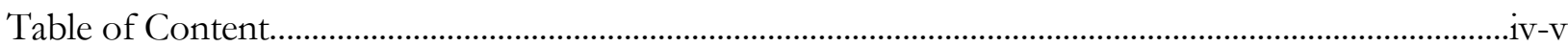

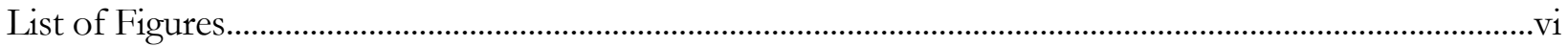

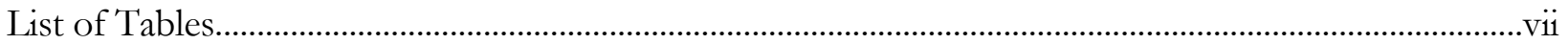

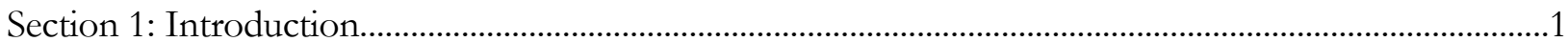

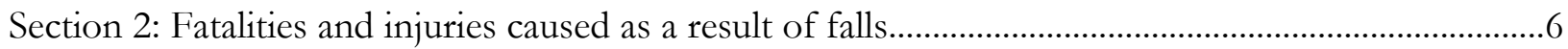

Section 3: 5 Type of Roofs Roofers Deal with and Recommended Materials to Top Each................12

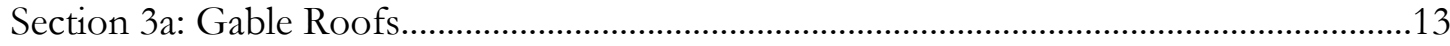

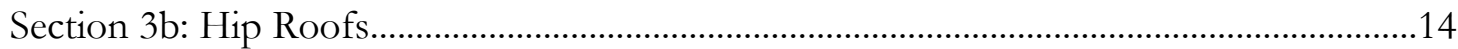

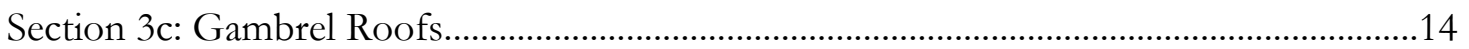

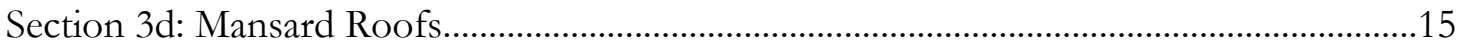

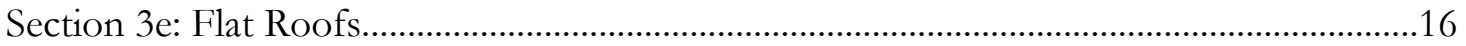

Section 4: Roof Slopes' Classification...........................................................................................................

Section 5: Roofing Materials Used by Roofers to Top Roofs and their Safety Quality..............................17

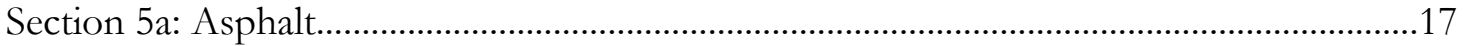

Section 5b: Wood Shingles or Shakes.........................................................................................18

Section 5c: Metal (Steel, Aluminum, Tin, Zinc, Copper).............................................................18

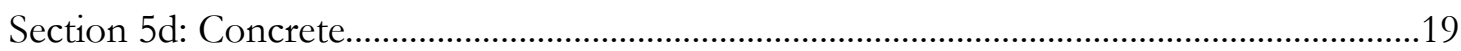

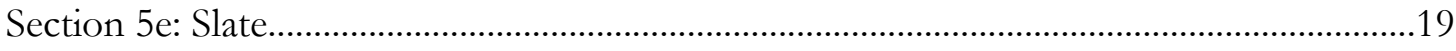

Section 5f: Rubber Roofing..............................................................................................19

Section 6: How Significant are Roofs, Roof slopes and Roofing Materials for Roofers' Safety?..............20

Section 7: Tools Roofers Use to Reach Roofs...............................................................................................22

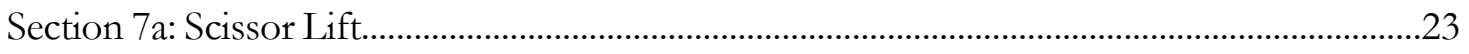

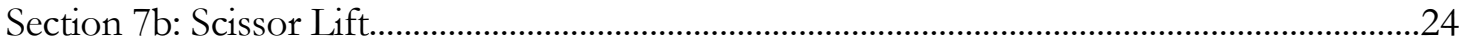

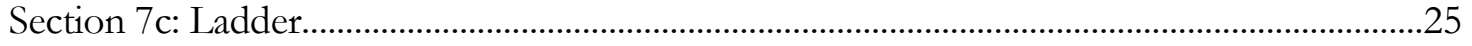

Section 8: Personal Fall Arrest Systems (PFAS) Used by Roofers....................................................................26

Section 8a: Angel Anchor System and CB-12 Anchor Point..................................................27

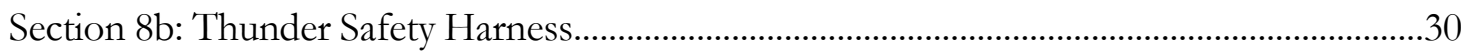

Section 8c: Shock absorbing lanyard and retractable life line..........................................................31 


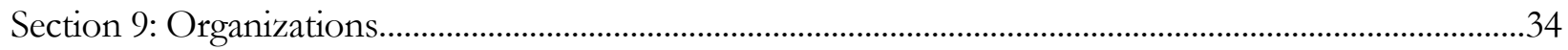

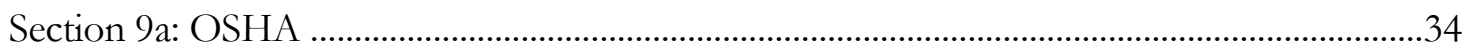

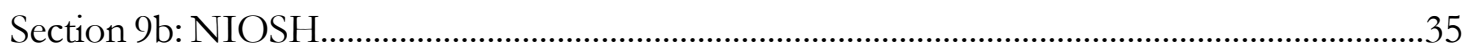

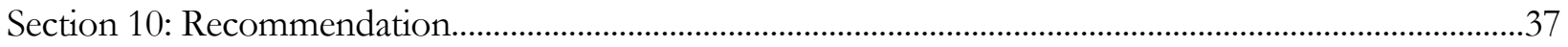

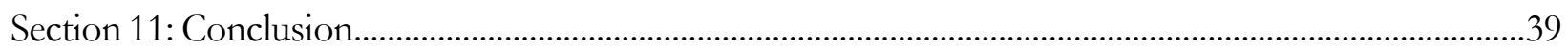

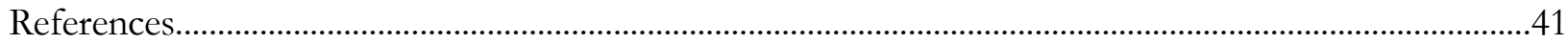


Figure 1: The market size of commercial roofing between 2015 and 2024 ............................................2

Figure 2: Percentage of the number roofing materials sold to consumers in 2014..................................3

Figure 3: Percentage of fatal and non-fatal ladder falls by fall height...........................................................

Figure 4: The use of personal fall arrest systems to prevent falls.................................................................5

Figure 5: The United States yearly average of causes of work-related deaths between 1992 1998........6

Figure 6: The United States yearly average of falls from different mediums between 1992-1998.........7

Figure 7: Causes of deaths in construction workers at different elevations between 2008-2010...........8

Figure 8: Fatal injury rate and total fatal injuries for construction workers between 2006 and 2016....9

Figure 9: Events contributing to construction worker fatalities as of 2016...............................................10

Figure 10: The rate of fatal injuries in construction across various occupations in 2015 and 2016.....11

Figure 11: Causes of non-fatal injuries from falls in construction at different elevations in $2010 . . . . . . .12$

Figure 12: Types of roofs that are constructed by roofers...........................................................................13

Figure 13: A comparison between the spaces obtained by Gable roof vs. Gambrel roof.........................15

Figure 14: Tools Construction Workers Use to Reach Roofs.................................................................23

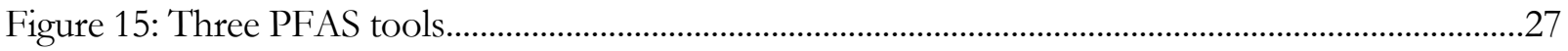

Figure 16: Allowable distances roofers can have by using Angel anchors..............................................28

Figure 17: CB-12 installation differences between wood, metal and concrete.........................................29

Figure 18: Calculating the potential falling distance using shock absorbing lanyard...............................32

Figure 19: Calculating the free fall clearance distance using SRLs.............................................................33

Figure 20: Some updates on roofing and fall protection rules between 1994 and 2014.........................35 


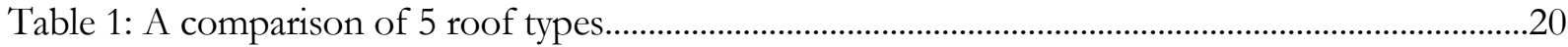

Table 2: Minimum roof live load of concrete roof slabs........................................................................21

Table 3: Summary of the differences between the tool's construction workers use ..............................25 


\section{Section 1: Introduction}

In construction, falling from roofs is a leading cause of injuries and deaths (Construction Focus Four, 2011). Roofing is also one of the most dangerous occupations in America (Cable News Network, 2010). For example, residential roofing is rated nine times more dangerous than the average occupation and three times more fatal than the average trade in construction (Moore and Wagner, 2014). As of 2016, roofing is rated as the fourth most dangerous occupation in the U.S. and accidents such as tripping, falling and slipping are common reasons behind it (Stebbins et al., 2018). According to OSHA, not having fall protection is the most cited violation in the construction industry (Jones, 2016).

A roofer can simply be defined as a person who installs, repairs and replaces buildings' roofs using various materials such as shingles and metal (Bureau of Labor Statistics "BLS", 2018). Roofs can be damaged by harsh weather conditions including snow falls and winds (Roof inspection checklist, 2007). However, $40 \%$ of roof damages are due to human errors such as bad maintenance and faulty installation (Vross, 2012). In order to avoid such conditions and detect roof problems early, regular inspection is required (Roof inspection checklist, 2007). The regular inspection for roofs can reduce the overall repair or replacement costs by 45\% (Fountaine, 2017). However, roofing, roof maintenance and inspection are not riskless.

Roofers are exposed to many hazards at great risk of bodily injury or illness associated with bad occupational conditions while performing their job (Protecting Roofing Workers, 2015). These hazards include (1) being exposed to high platforms; (2) dealing with power tools; (3) working in dangerous condition where roof materials and surfaces are wet and slippery; and (4) inhaling hazardous toxins and various chemicals that are used in roofing materials such as lead and asbestos (Morton, 2015). 
This research will shed light on the roofing materials that have shown to greatly contribute to roofer falls. The increase in society's disposable income, as well as the rate of urbanization and commercialization have significantly impacted the growing market of roofing materials as seen in Figure 1 and is expected to increase over the years (Variant, 2017).

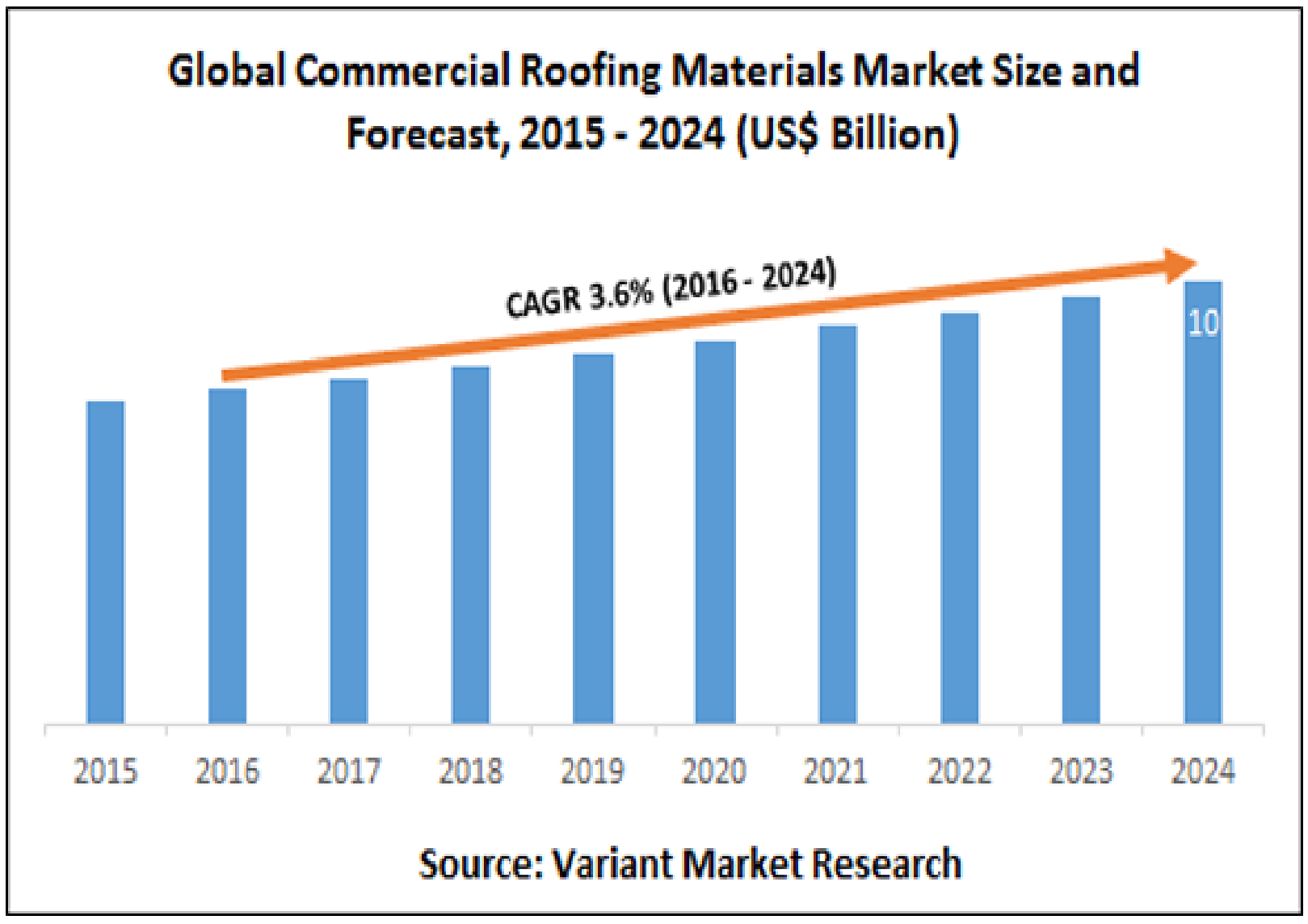

Figure 1: The market size of commercial roofing between 2015 and 2024 (Variant, 2017)

As shown in Figure 2, statistics have shown that in 2014, asphalt was the most widely used roofing material compared to others. Asphalt at its molten state generates a high volume of toxic fumes and according to OSHA, can have an undesirable chronic health effect on roofers. As well, the generated fumes can cause fatigue and put workers at risk for lung cancer (OSHA, 2016a). 


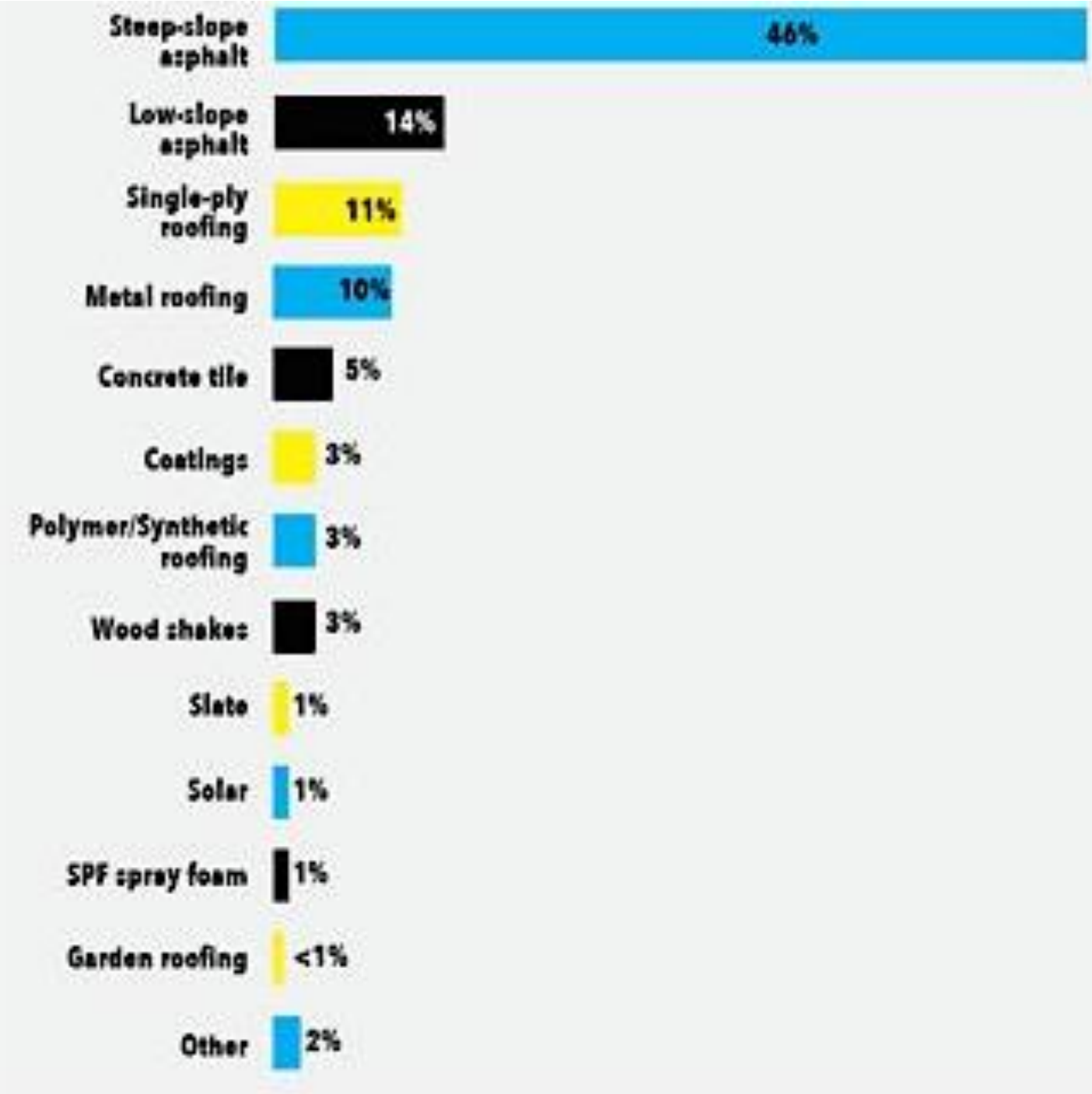

Figure 2: Percentage of the number roofing materials sold to consumers in 2014 (Yellow Blue Tech, 2014).

Ladders and scissor and boom lifts have been selected as the roofing tools for discussion in this paper. As shown in Figure 3, ladders have shown to contribute significantly to fatal and non-fatal fall injuries at different fall heights (Centers for Disease Control and Prevention "CDC", 2011). Scissor and boom lifts contribute to 2 - 3\% of overall deaths in construction. Falling from the lifts' buckets is one of their death causes (Elcosh, 2001). These lifts (boom \&scissor) can be hazardous if placed on uneven 
surfaces and driven into holes. Also, operating the lifts in unpleasant weather conditions (rainy or snowy) or low visibility states can cause falls. Hiring inexperienced and/or untrained personnel prior to the lifts' usage can also put them at risk of falls (Roofing contractor, 2003).

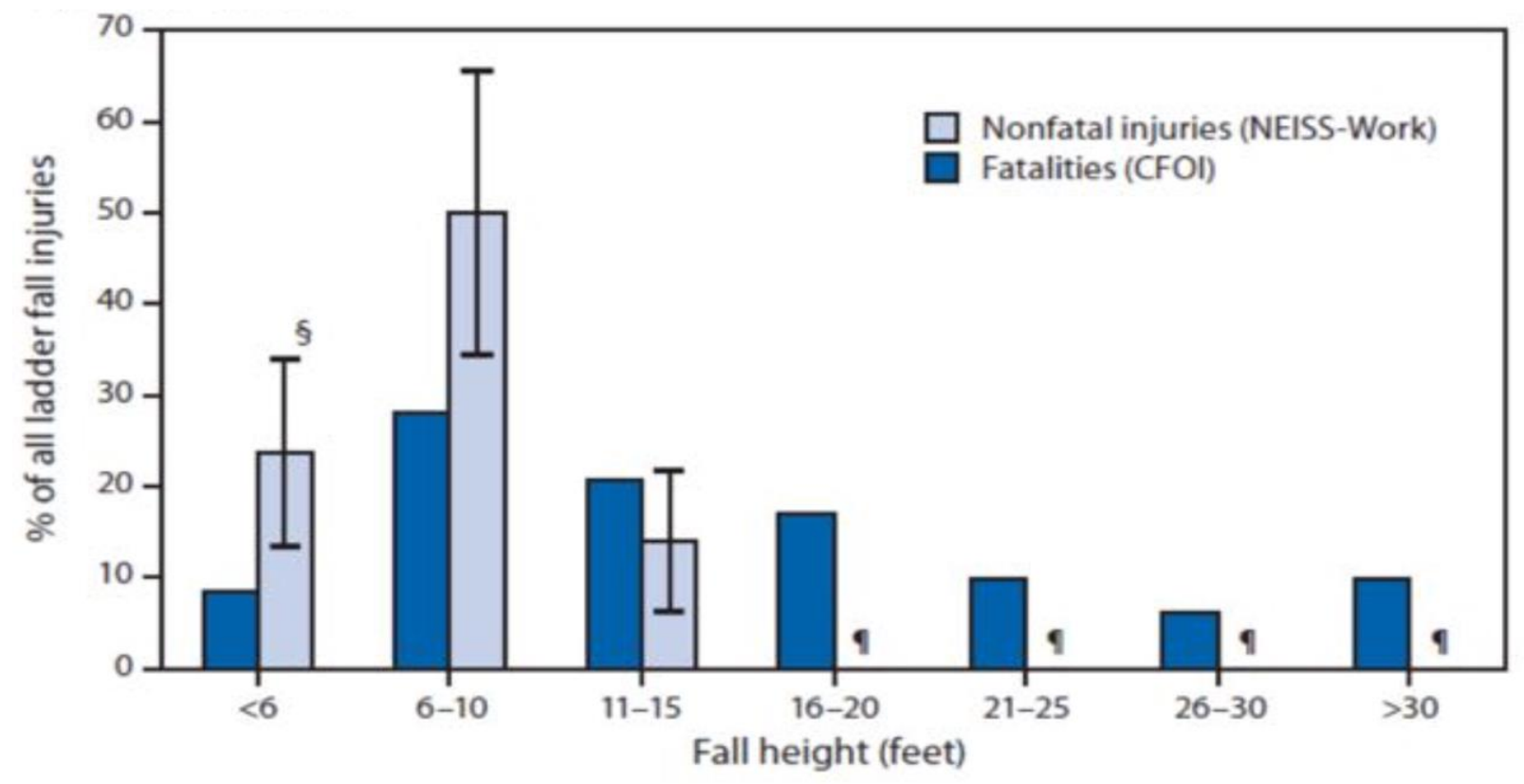

Figure 3: Percentage of fatal and non-fatal ladder falls by fall height (CDC, 2011)

Three personal fall arrest system (PFAS) tools have been identified and will be elaborated on. PFAS is made up of three components according to OSHA (Protecting Roofing Workers, 2015), these include an anchorage e.g. Angel anchor system and CB-12 anchor point, a full body harness e.g. thunder safety harness, and a lifeline or lanyard e.g. shock absorbing lanyard and retractable life line. These various tools according to the OSHA standards are being used by roofers so that they can avoid fall risks during their job, as shown in Figure 4. In primitive times, little to no fall protection equipment such as body belts were used to secure construction workers from falls (Rigid Lifelines, 2012). Through the use of these PFASs, the safety of roofers has shown to improve greatly. However, this requires compliance 
with certain construction and safety rules (Protecting Roofing Workers, 2015). The roofing tools used to get onto the roof such as ladders, scissor and boom lifts; the PFAS to help secure the roofer to the roof; the roofing materials used to construct the roof; and the structure or type of roof are all connected and regarded as important factors for roofers' safety. This paper will further analyze the various practices and concepts involved in roofing and how these practices and concepts are holistically connected to affect roofers' safety.

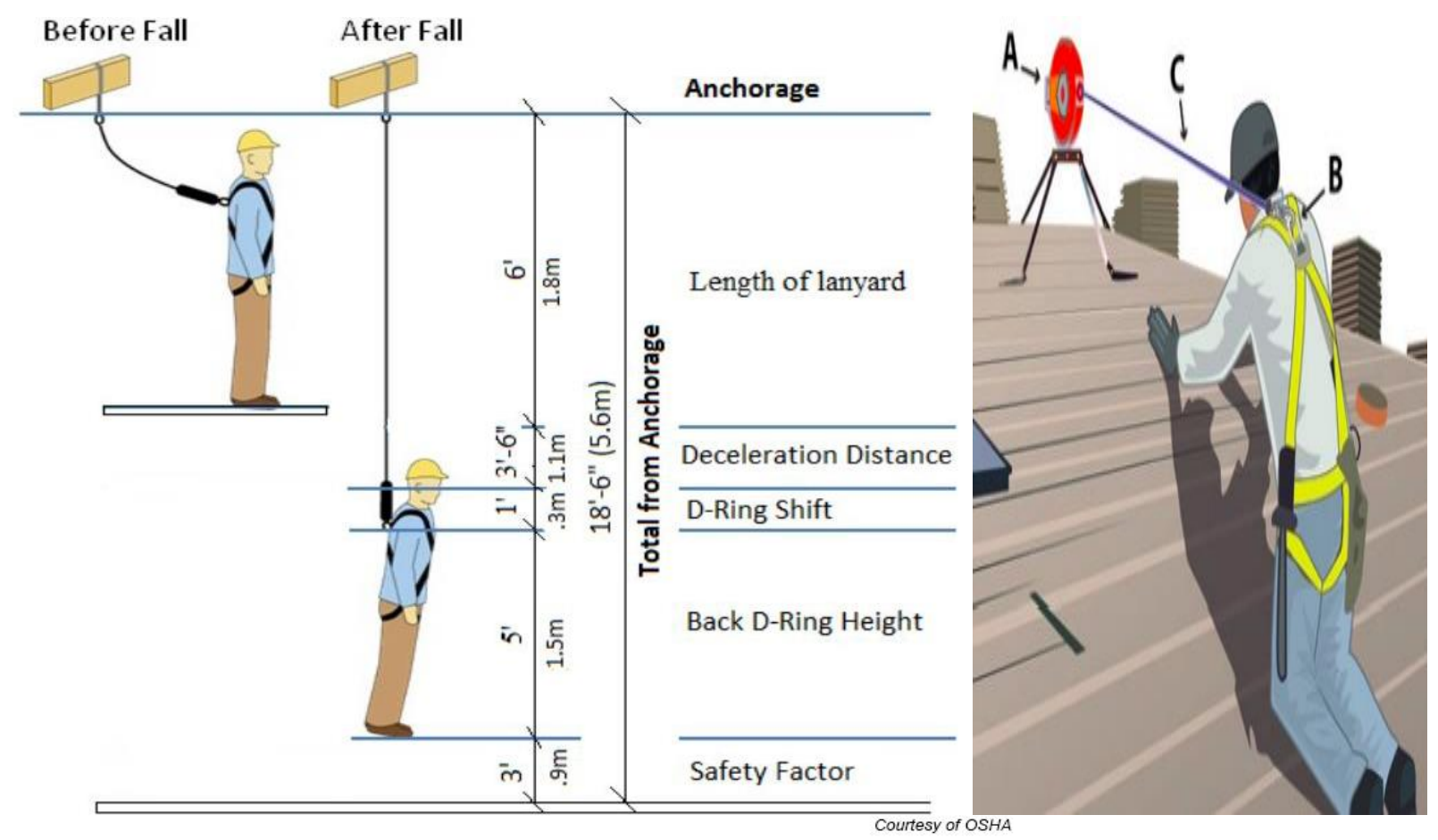

Figure 4: The use of personal fall arrest systems to prevent falls (Protecting Roofing Workers, 2015)

The objective of this study is to review and analyze roofing practices that influence roofers' safety which include dealing with various roof types, their roofing materials, as well as previously mentioned lifting tools and PFAS. This study will also discuss the role of OSHA as well as NIOSH in protecting roofers and minimizing their fatal and non-fatal injuries and conclude with an overall recommendation list for enhancing their safety. 


\section{Section 2: Fatalities and Injuries Caused as a Result of Falls}

As the construction industry continues to grow, so does its reputation in being one of the major contributors to annual worker deaths (Jones, 2016). According to the Bureau of Labor Statistics' 2016 Census of Fatal Occupational Injuries, there were about 5,190 fatal occupational injuries that occurred in the U.S. In the construction industry, there were about 991 deaths of workers (BLS, 2018), which contributed to $19.09 \%$ of the total fatal injuries. Falling was the top accident type for work-related deaths among others. Between 1992-1998 fall deaths were already exceptionally high compared to other causes as shown in Figure 5 and falls from roof ledges already constituted three quarters of fall deaths during this period compared to other means as shown in Figure 6.

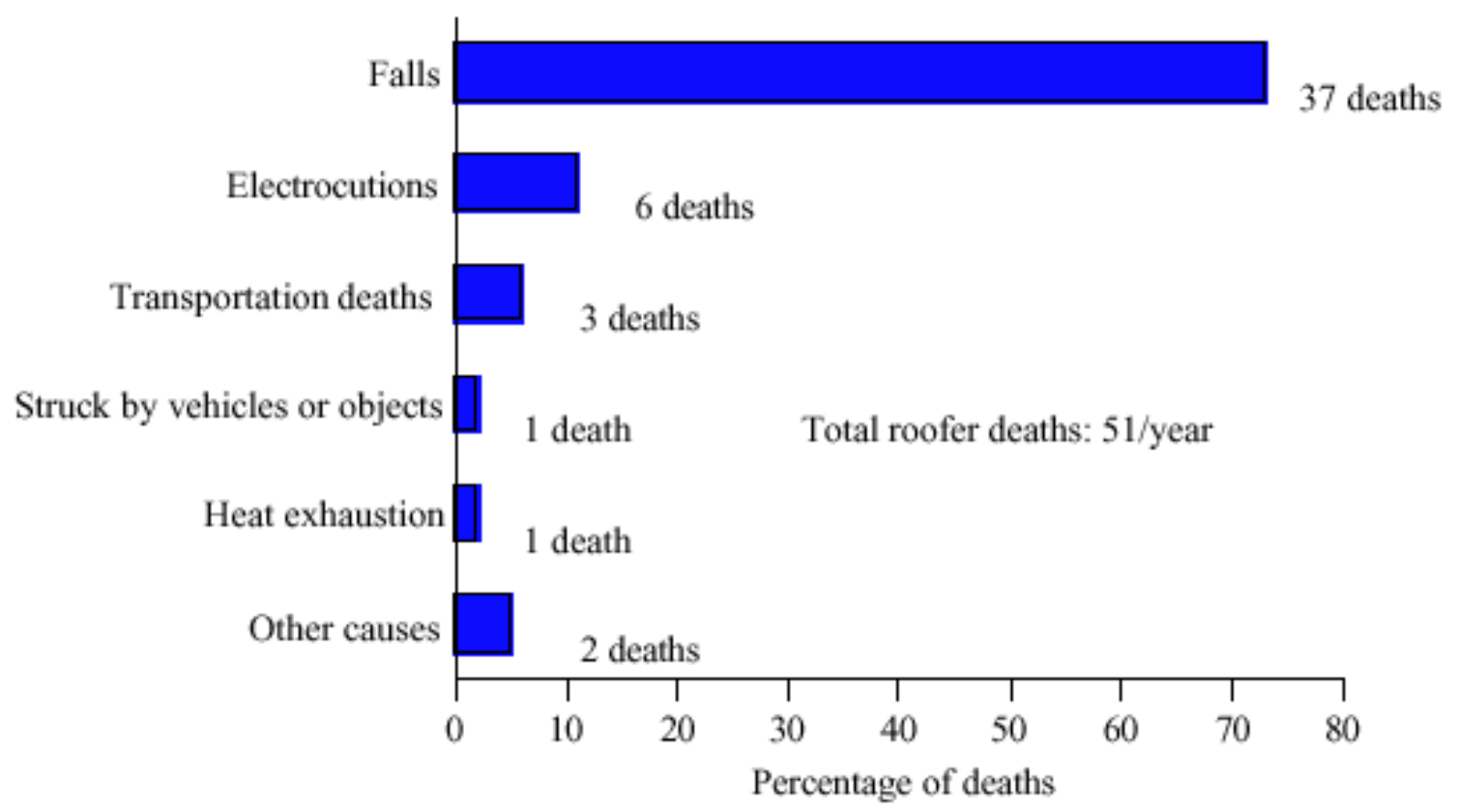

Figure 5: The United States yearly average of causes of work-related deaths between 1992-1998 (Elcosh, 2017). 


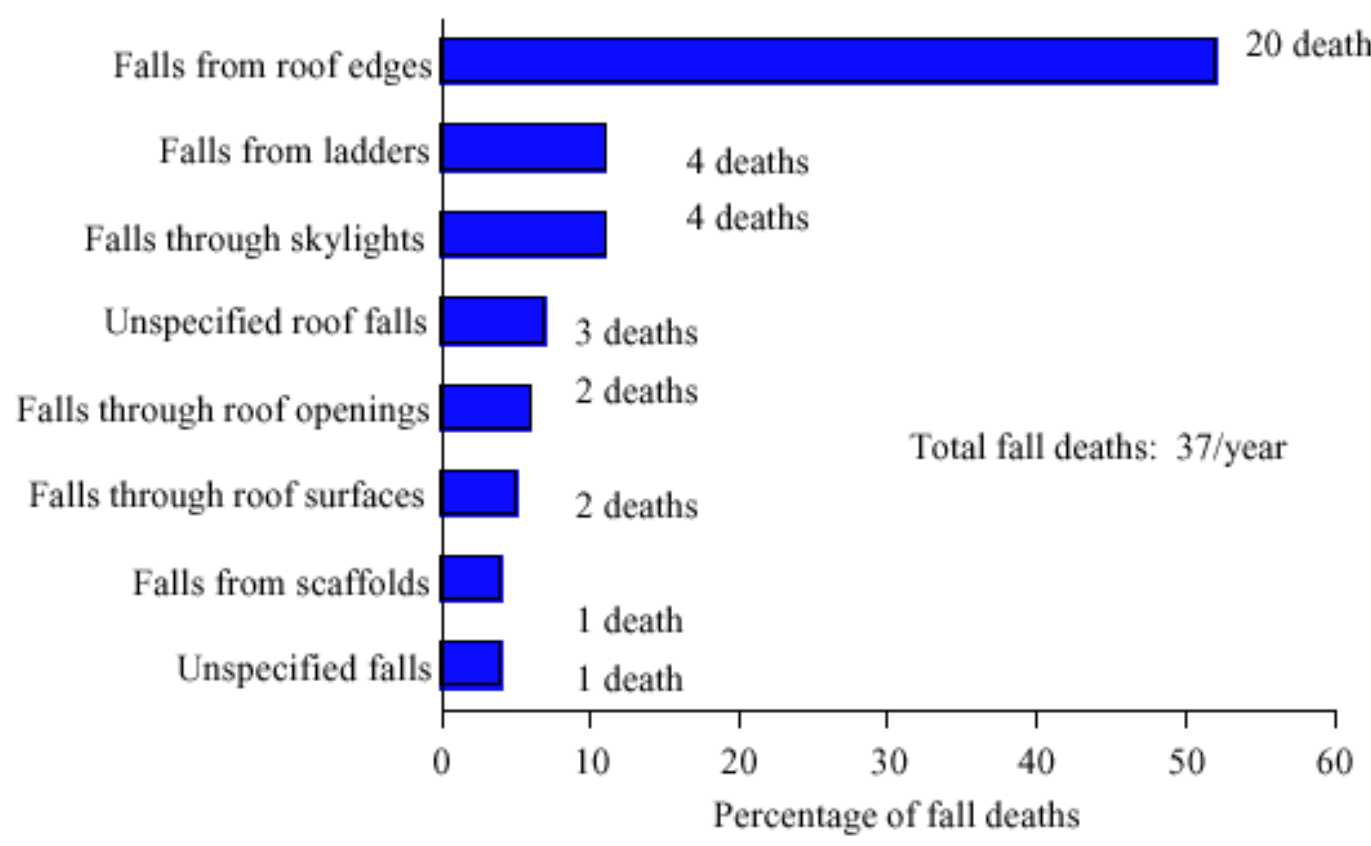

Figure 6: The United States yearly average of falls from different mediums between 1992-1998

(Elcosh, 2017)

Figure 7 below, shows the recorded number of deaths due to falls at different heights amongst construction workers between the time period 2008-2010. There was a total of 891 fatalities with falling from roofs $(31 \%)$ and ladders $(23.6 \%)$ being main reasons for these deaths. Other causes include: falling from scaffolds (14.6\%), non-moving vehicles (7.1\%), steel girders (6.7\%), ground level (4.9), and others $(6.1 \%)$. 


$$
\text { Total }=891 \text { deaths }
$$

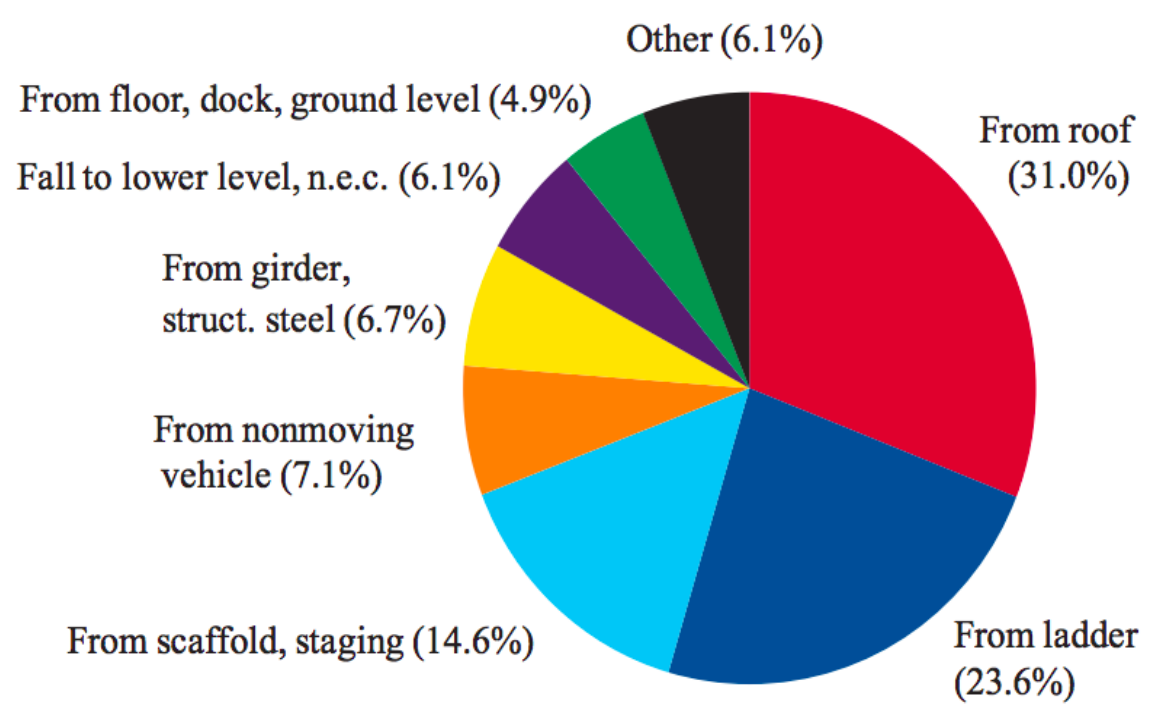

Figure 7: Causes of deaths between construction workers at different elevations between 2008-2010 (The Center for Construction Research and Training “CPWR”, 2013)

Figure 8 shows the fatal injury rate and total fatal injuries amongst construction workers, which occurred between the periods of 2006 to 2016. From 2015 to 2016, the construction industry had witnessed a growth of $6 \%$ in the death of workers. During that period (2015-2016), workers who had suffered fatal injuries in the construction industry remained at a rate of 10.1 per 100,000 full time equivalent (FTE) workers. For all occupations (constructional and non-constructional), the total fatality rate for all injuries increased from 3.4 to 3.6 per 100,000 FTE between 2015 and 2016 (Jones, 2017). 


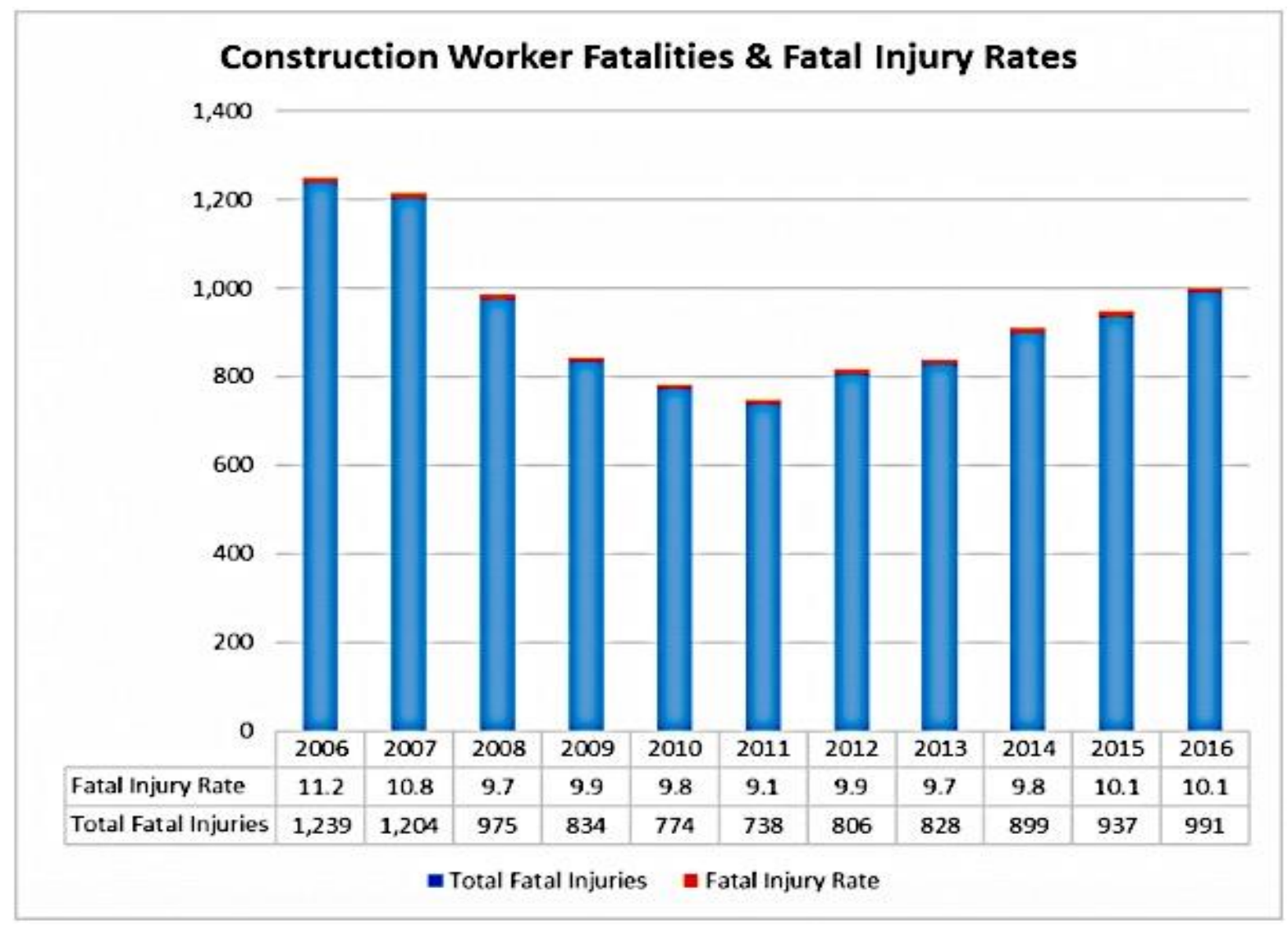

Figure 8: Fatal injury rate and total fatal injuries for construction workers between 2006 and 2016

(Jones, 2017).

Figure 9 shows that falls, slips, and trips are the primary cause of many deaths between construction workers constituting 39\% of all construction worker deaths. According to OSHA, 384 out of 991 total deaths occurred amongst construction workers due to falls in 2016 (Common Stats, 2017). 


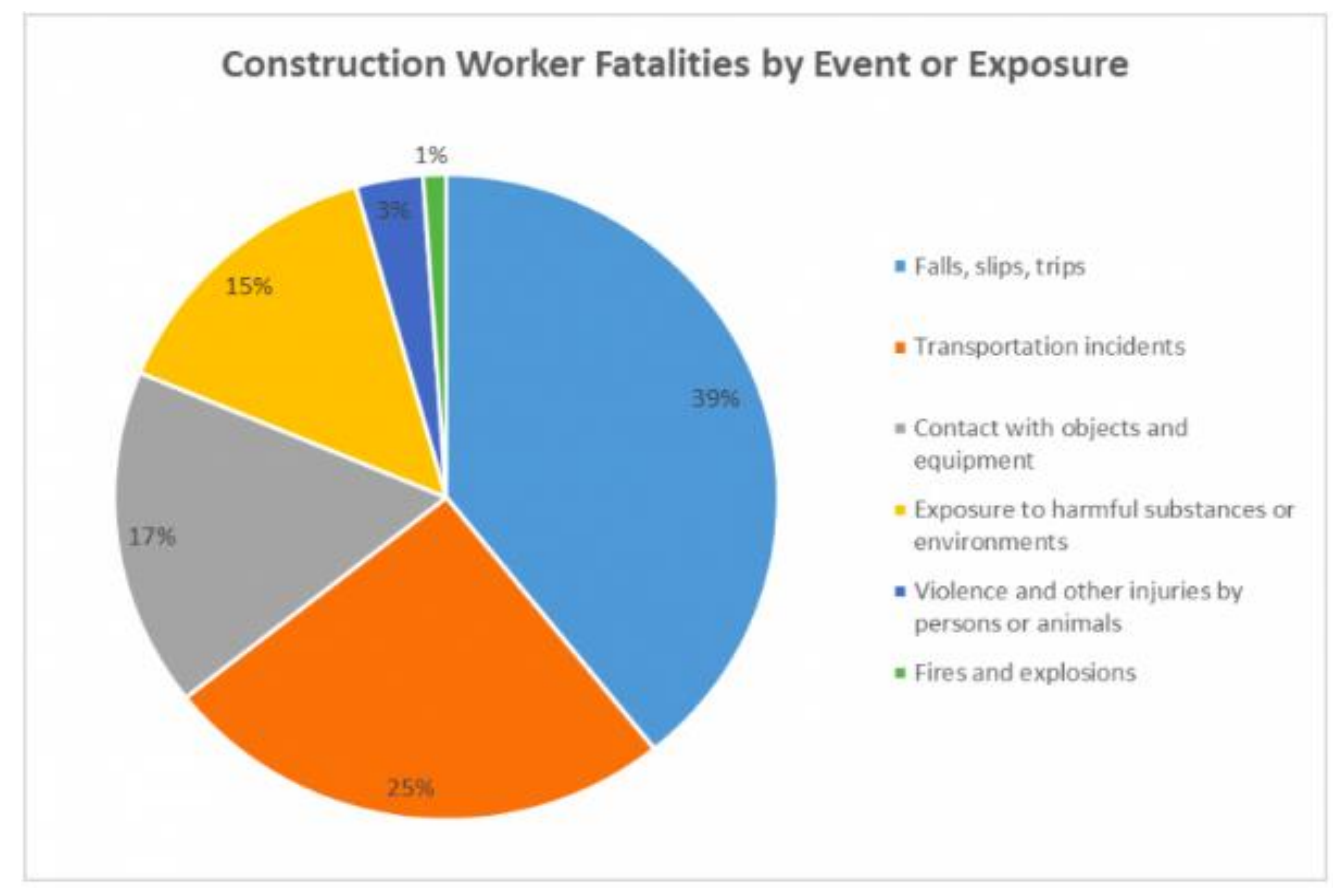

Figure 9: Events contributing to construction worker fatalities as of 2016 (Jones, 2017)

As illustrated in Figure 10, roofers suffer the highest fall rates resulting in fatalities, which has reached 48.6 in 2016 compared to 39.7 in 2015 for every 100,000 FTE workers. This is due to the failure of employers to provide ample fall protection, which is in violation of OSHA laws and regulations (Jones, 2017). As a result of the fatal injury rate for roofers, this occupation is now the fourth deadliest job across all other occupations (Jones, 2017). 


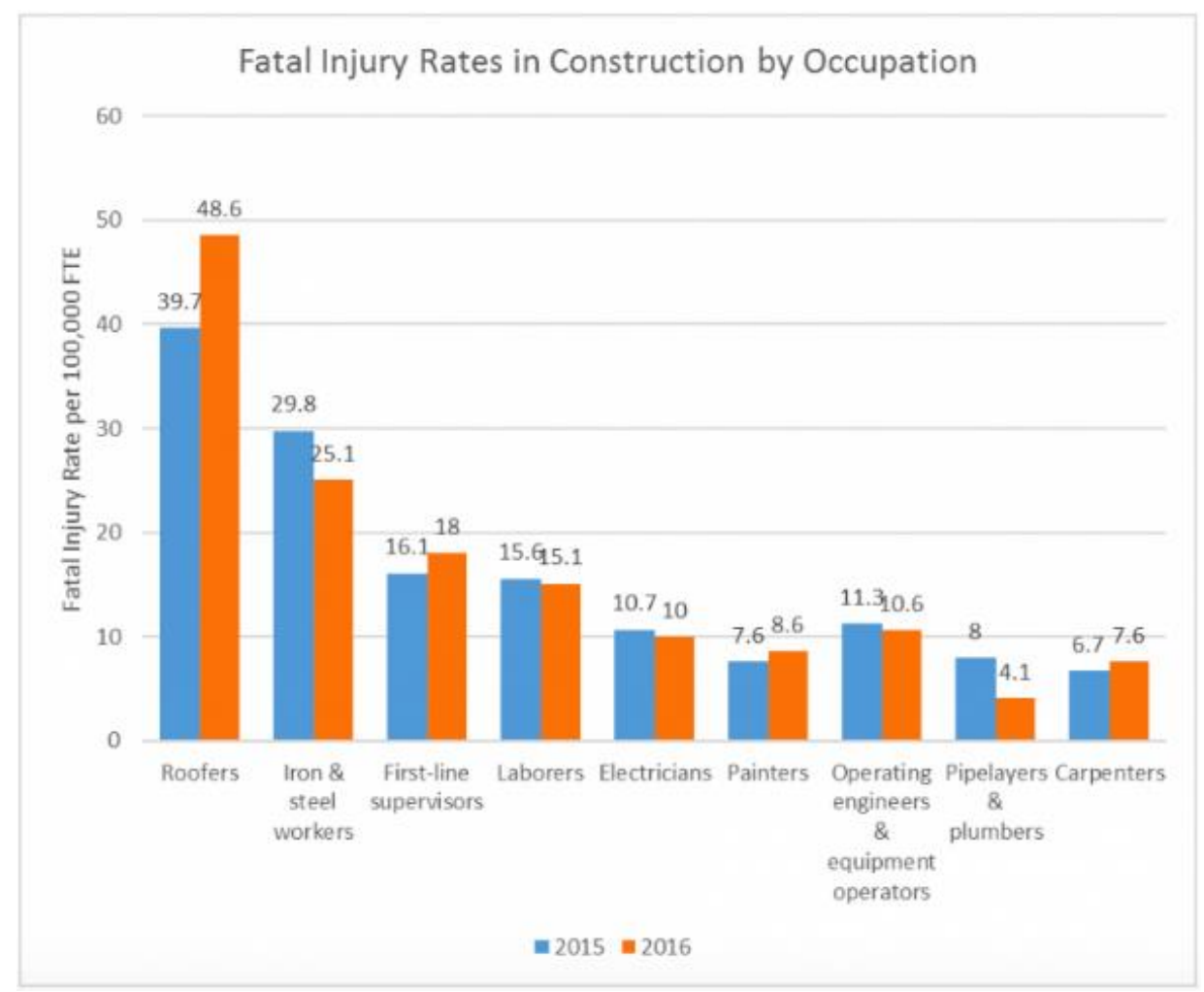

Figure 10: The rate of fatal injuries in construction across various occupations in 2015 and 2016 (Jones, 2017).

Figure 11 shows the causes of non-fatal injuries from falls amongst construction workers at different elevations in 2010. The highest recorded percentage is on the sudden balance loss (falling) after walking on a level surface (on the same-level) (Nelson \& Associates, 2006). The second cause is falling from ladders and thirdly roofs accounting for $7.3 \%$ of the total non-fatal fall injuries. When a roofer falls from a roof, he/she can fall on a particular part of their body where the force is strong enough to break their bones. Another common injury that occurs is paralysis caused by severe injury to the spinal cord, which can happen when a roofer falls off the roof and tries to grab onto an object to try and prevent the fall. As a result of this, the worker can twist a section of their body during the fall causing them to fall on their chest, back section, or head. The impact caused to these sections of the body can damage 
the spinal cord and thus lead to paralysis (Kumar, 2010). Other common injuries from falling include traumatic brain injuries which can cause permanent health side effects; depressed fractures to the skull; hemorrhaging; pulmonary contusions; damage to the bronchus or aorta where vessels are ruptured; back injuries; and damage to the internal organs (Kumar, 2010).

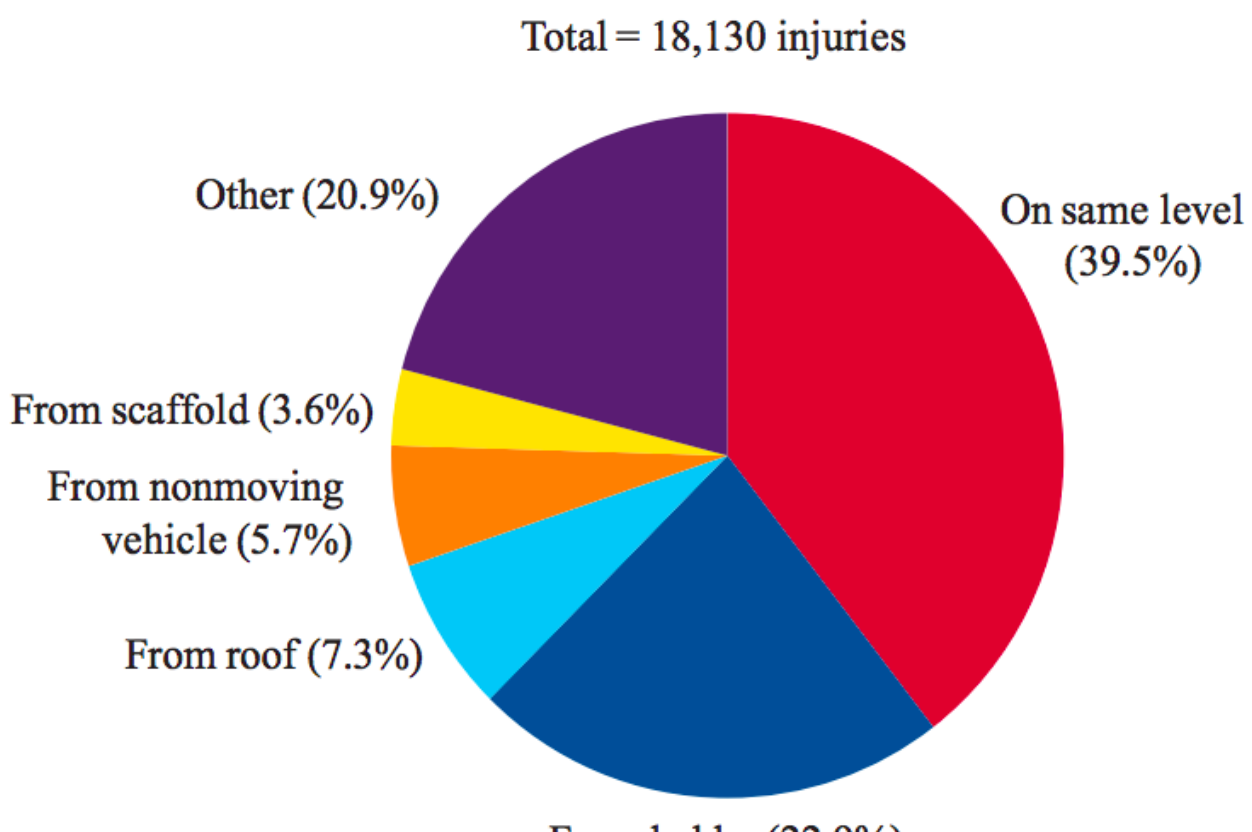

From ladder (22.9\%)

Figure 11: Causes of non-fatal injuries from falls in construction at different elevations in 2010

(CPWR, 2013)

\section{Section 3: 5 Type of Roofs Roofers Deal with and Recommended Materials to Top Each}

Roof shapes or types differ greatly as one moves from a region to another. The factors that influence the shape and selection of roofs are their endurance to withstand various weather conditions and whether the material used in their construction is available in the home owner's residence area. (Big Al, 2017). Figure 12 shows 5 different types of roofs, each having its own advantages and disadvantages, which will be further elaborated on herein. 


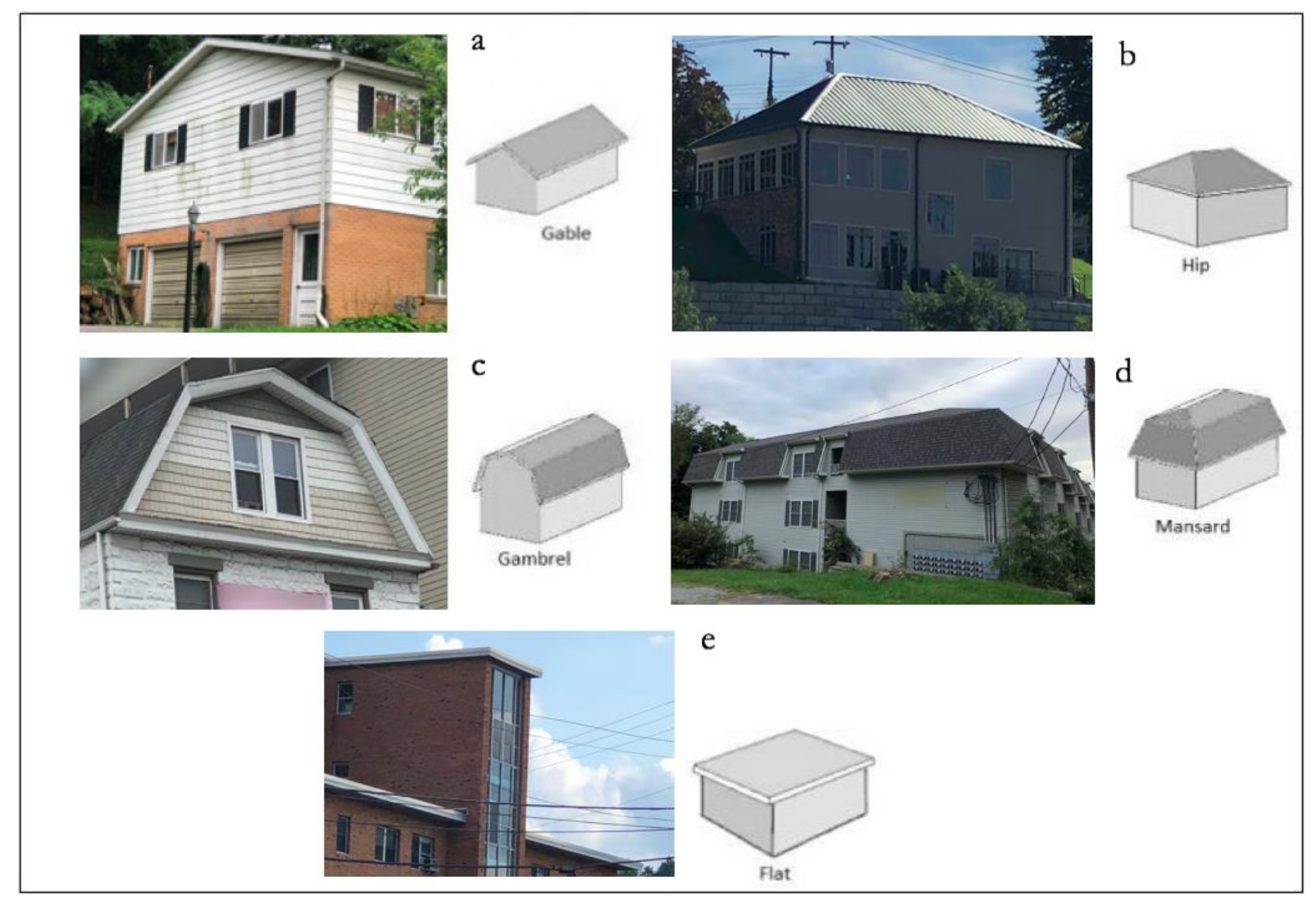

Figure 12: Types of roofs that are constructed by roofers (Images by: Shishtar, 2018, Drawings by: Big al, 2017)

\section{Section 3a: Gable Roofs}

Gable roofs (Figure 12a) are also commonly known as pitched or peaked roofs and are one of the most well-known roofs among US residents and are easily identified by their triangular shape. Different types of gable roofs exist, which include side gable, cross gable, front gable and Dutch gable roofs (Big Al, 2017).. This unique design is appropriate for homes that have separate wings and can be used to accent different sectors of the house. The benefit of this roof type is that rain and snow are able to easily fall off the roof. This roof type further introduces additional space in the home and increases ventilation (Big Al, 2017). 
The downside to this roof type is that when the roof is exposed to extreme windy conditions especially in high risk hurricane areas, improper support can cause the materials used to build the roof to dismantle or cause the roof to collapse. Strong winds can also cause the entire roof structure to separate from the walls of the house (Big Al, 2017). The Gable roof structure frequently comprises a vast array of materials. These materials typically contain asphalt shingles, cedar (wooden) shakes, metal or concrete tiles. Where structures such as the valley or hip style are present, they should include metal shingles or standing materials as these minimize leakage (Big Al, 2017).

\section{Section 3b: Hip Roofs}

Hip roofs (Figure 12b) possess a slope on all four sides as each side has equal lengths to its opposite side. All four sides meet and form a ridge structure, and like the gable roof can be covered using any type of materials. Different types of hip roofs exist, which include simple hip, cross hip and half hip (Big Al, 2017). These roofs provide more stability than gable roofs. The four-side design allows the roof to be sturdier and more durable. Hip roofs are able to withstand extreme weather conditions such as strong winds and snow. The slanted design structure of the roof allows water and snow to funnel off the roof surface (Big Al, 2017). Just as with the previous example, the hip roof is also conducive to the provision of further space in the home, such as a crow's nest or dormer. Hip roofs are similar to gable roofs and can also be made using a wide range of materials such as asphalt shingles, metal, or concrete tiles (Big Al, 2017).

\section{Section 3c: Gambrel roofs}

Gambrel roof (Figure 12c), also commonly known as barn roof, has two dissimilar slopes in its structure. Like Gable roofs (figure 12a), the Gambrel roof is accompanied by only two similar sides. The lower slope of the Gambrel roof has a vertical and steep structural appearance whereas the upper slope 
is much lower (Big Al, 2017). Barns frequently feature the Gambrel roof style, as do farmhouses and even log cabins. The Dutch Colonial style often has a Gambrel roof and this style is further used in Georgian architectural structures. This roof type provides extra living quarters such as the garret, attic or loft, which is similar to the Mansard roof (which will be discussed). Gambrel roofs are also ideal for outdoor sheds as well as buildings used for storage as its unique shape provides more storage without utilizing more space (Big Al, 2017). Figure 13 below shows how gambrel roof can have an extras pace at the upper portion of its structure in comparison with Gable roofs.

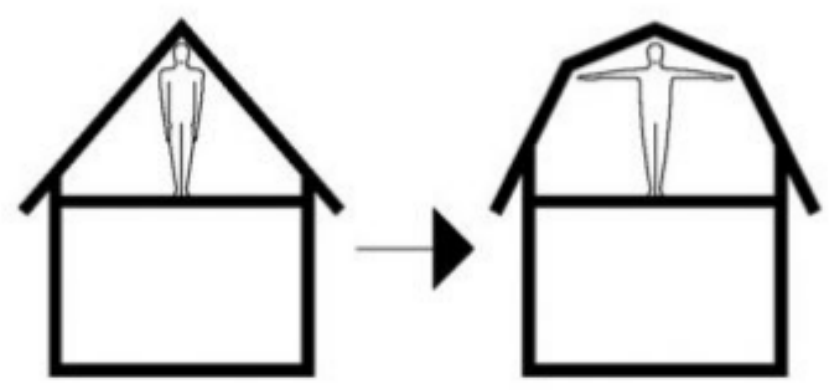

Figure 13: A comparison between the spaces obtained with a steep Gable roof vs. low slope upper and steep lower Gambrel roof (Woodsman, 2017).

This roof structure is not designed for use in regions, which experience either heavy snowfalls or strong winds. If high pressure is placed on the open design, this may result in the roof collapsing on it. This roof type requires solid construction, needs to be waterproofed at all edges and has to be maintained regularly. Gambrel roofs require annual inspection to investigate whether the roof has been damaged by extreme weather conditions. The material used in this roof type includes wood, asphalt or slate shingles (Big Al, 2017).

\section{Section 3d: Mansard Roofs}


The mansard roof (Figure 12d) is also commonly referred to as a French roof (Big Al, 2017). This roof type comprises of four structural surfaces, featuring a double slope for each section, giving this structure four slope pitches. The low Mansard roof angle possesses a far more obvious angle than that of the higher slope (Sadheghi \& Mohandes, 2013). Depending on the owner's preferences, roof sides can be either curved or feature a flat style. The unique design of this roof recommends making use of long life materials such as metals. Other allowable materials include wood, slate and asphalt shingles. Mansard roofs are provided in a variety of shapes which include straight angled, convex or concave (Big Al, 2017). Using a low-pitched top design of Mansard roofs provides an added disadvantage to this roof type as it is not stable enough to endure heavy snowfalls, therefore they are better not to be built in areas exposed to extreme weather conditions (Big Al, 2017).

\section{Section 3e: Flat Roofs}

The flat roof (Figure 12e) is completely flat and only possesses a small pitch, which allows water to run off the roof as it requires excellent drainage. Flat roofs are more commonly used on industrial or commercial buildings and can be constructed for houses in areas, which receive high and low rainfall. (Big Al, 2017). The flat surface of the roof provides extra living space which is ideal for patios or gardens. Flat roofs provide a great platform for structures that provide heat or cool air to buildings as it can be well hidden. The flat surface also provides an excellent platform for the installation of PV solar panels, which save more energy for the building and are relatively easy to build and cost effective due to the small amount of materials used (Big Al, 2017). The limitations of flat roofs are that they are more prone to water leakages and are not ideal for snowfall areas that can potentially require them frequent maintenance, repairs and replacements. The materials used to construct this roof type require it to be waterproof. Frequently used materials include metal sheets, and rubber membrane (Big Al, 2017). 


\section{Section 4: Roof Slopes' Classification}

Roofs can come in a variety of shapes as well as different steepness and slopes. Roof slopes are classified as the following: Flat roof (2/12 vertical/horizontal or $4.76^{\circ}$ or less), Low slope $(2 / 12$ - 4/12 $=4.76^{\circ}$ to $\left.18.4^{\circ}\right)$, Conventional slope roof $\left(4 / 12-9 / 12=18.4^{\circ}\right.$ to $\left.36.5^{\circ}\right)$, Higher Slopes: $9 / 12-20 / 12$ $=36.5^{\circ}$ to $59.0^{\circ}$, Steep slope: $21 / 12$ and higher $=60.3^{\circ}$ or more $($ How Slope Your Roof Determines, n.d). Generally, roofs with slopes greater than 4/12 are classified as "steep-roofs" (Interpretations and Clarifications, 1995). Most single family homes in the U.S. are framed with a steep slope roof pitch. commercial buildings have flat roof designs. Also, many residences do have low slope roofs (How Slope Your Roof Determines, n.d).

\section{Section 5: Roofing Materials Used by Roofers to Top Roofs and their Safety Quality}

\section{Section 5a: Asphalt}

The advantages are that this material is long lasting and can withstand normal weather conditions and can come in vast variety of colors and shapes (Coe, 2017). It is the cheapest in comparison to the rest of roofing materials such as concrete (Krow, n.d). This is an indication that roofers deal with Asphalt more than other roof types as its affordability attracts customers and house owners.

Maintaining this material regularly can prolong its longevity up to 30 years (Coe, 2017). Asphalts come in two different conditions, shingles and liquefied or molten state. Each has its own specifications. Among all other roofing materials, more than $75 \%$ of U.S homes top their roofs with asphalt shingles (Your Guide to Asphalt, 2017) and used for a vast variety of roof slopes including steep and low slope roofs (Yellow Blue Tech, 2014). Asphalt is also easy to repair rendering it simple to fix cracks. This material is very versatile and can be molded into a variety of shapes. Thus, it is able to suit different types of roofs with different sizes (Coe, 2017). 
However, Asphalt is also greatly affected by weather conditions that can cause the material to become soft and flexible when exposed to hot temperatures and brittle when exposed to cold temperatures, which can cause cracks and allow the material to break on impact. Asphalt at its liquefied form is unsuitable for roofs that possess an overly sloped structure as the material is applied to a roof can run off the roof thereby preventing it from setting properly (Coe, 2017). The temperature range that is required to liquefy traditional asphalt is 250-350 degrees Fahrenheit (Krow, n.d). OSHA warns all construction workers (roofers included) about Asphalts when they are at their molten states as inhaling their fumes can be toxic and causes lung cancer (OSHA Archive, 2016).

\section{Section 5b: Wood Shingles or Shakes}

This material has a great natural appearance that weathers to softer grey color. It provides the roof with insulation and blends in naturally with the surrounding environment. The material is fairly easy to replace and repair as well, and if well maintained can last for a period of 30-50 years (Desmesne, 2018). Wooden shingles require very high maintenance as the material can easily rot and develop mold or mildew. Further, it's not strongly resistant to fire unless it undergoes a pressure treatment (Desmesne, 2018). Depending on the wooden type used for roofing, they can contain $15 \%$ - $25 \%$ of moisture content (Cedar Roofing, 2016), in which it can put roofers' life in jeopardy specially in rain or snowfalls resulting in slipping or falling. Therefore, dealing with wooden shingles is not simple as they require a professional to install, clean or do maintenance work on them (Cedar Roofing, 2016).

\section{Section 5c: Metal (Steel, Aluminum, Tin, Zinc, Copper)}

Metal is available in a variety of forms which includes tin, zinc, aluminum, copper, or galvanized steel (Wondering about Mental, 2017). It is very strong and light (ASC Building Products, n.d) and durable as it can last for up to 40 to 70 years (Wondering about Mental, 2017). It can also withstand weather 
conditions such as high winds as well as rain, and is environmentally friendly (Desmesne, 2018).

Depending on the type, it sustains wind guests up to 140 miles/hour and is impact-resistant

(Wondering about Mental, 2017). However, by time it requires frequent painting (Desmesne, 2018).

\section{Section 5d: Concrete}

This material is non-combustible, it comes in an array of colors as well as styles, it is visually appealing, can withstand fire, relatively easy to maintain and is durable when it is maintained in a proper fashion (Desmesne, 2018). Concrete have the ability to withstand intense winds and excessive rainstorms. Buildings that use concrete roofs can have a lifetime longevity if they are properly installed and regularly maintained (Jayhawk Exteriors, 2015). The downside is that this material is very heavy, and should be mainly used in new constructions as it is dependent on weight and goes under structural requirements (Desmesne, 2018). Concrete is a strong material (Jayhawk Exteriors, 2015), therefore, the ability to handle roofers' weight is assured.

\section{Section 5e: Slate}

Slates are visually appealing, can withstand fire, have good longevity and require low maintenance. On the other hand, they are very heavy and are mostly dependent on a professional installation, and can be very fragile and breakable. (Desmesne, 2018). Fragility can have an undesired consequence upon roofers when stepping or walking on roofs.

\section{Section 5f: Rubber Roofing}

Rubber roofing has good longevity; is easy to repair, needs low maintenance and minimal roof leakages; can withstand extreme weather conditions such as high winds and hails; is environmentally friendly; and is fireproof (United Home Experts, 2018). Rubber roofing however is not visually appealing and requires a professional for installation (United Home Experts, 2018). When using a rubber roofing 
on a flat roof, a very minimal to non-damage whatsoever occurs when it's being stepped on (Steve Roofer, 2013), resulting in a safe environment for roofers working on it. Table 1 summarizes the early discussed roof types along with their structure and the different materials that are used to construct them.

Table 1: A comparison of 5 discussed roof types in terms of their structure and their building materials.

\begin{tabular}{|c|c|c|}
\hline Roof type & Structure of roof & Materials \\
\hline Flat & Flat & Metal sheets or rubber \\
\hline Mansard & $\begin{array}{c}\text { Straight angled, convex, } \\
\text { concave (four sided) }\end{array}$ & Whingles, metal or concrete tiles \\
\hline Hip & Slanted slope (four sided) & Wood or asphalt or slate or metal \\
\hline Gambrel & $\begin{array}{c}\text { Vertical lower and low-sloped } \\
\text { upper (two sided) }\end{array}$ & $\begin{array}{c}\text { Asphalt, shingles, wooden shakes, metal, and } \\
\text { concrete tiles }\end{array}$ \\
\hline Gable & $\begin{array}{c}\text { Pitched or peaked with steep } \\
\text { edges (two sided) }\end{array}$ & \\
\hline
\end{tabular}

\section{Section 6: How Significant are Roofs, Roof slopes and Roofing Materials for Roofers' Safety?}

These designs of roofs may be holistically beneficial to the owner of the house as these roof shapes have significance on the safety of roofers. This section introduces the concept of roofers' safety of roof potential hazards, slope of the roof, and roofing materials.

The roofs of households and buildings prove to be a land mine for many potential hazards. Many tools and elements contribute to unsafe conditions. Among these are skylights, parapet walls, extreme heat by cool roofs, slippery conditions, and others (Morton, 2015). Despite the many roof types and structures, roofs in general are not designed for handling pressure from continuous foot traffic. The inspections and repairs done by roofers require the roofer to walk gently across the various membranes and different panels of the roof. Roofers' trips, slips and falls lead to their death or at least cause severe injuries. This is all due to the high risks involved in this type of work (Morton, 2015). 
The slope of the roofs, no matter what material is used, does affect roofers' safety. According to OSHA, "Rain can make surfaces extremely slippery, especially on steep-slope roofs." (Roofing Industry, 2017). Therefore, steep-slope roofs are more hazardous than low-slope roofs, and the likelihood of falling increases as well. Since flat roofs are flat, they have lower falling possibility than other roof types (Cable News Network, 2010). Table 2 below, compares the minimum allowable live load on both flat roofs and sloped roofs with different pitch ranges of reinforced concrete slabs. It is shown that the distributed live load should decrease as the pitch slope rises. As well, flat concrete roofs have the highest live load values in terms of distributed load \& concentrated load in comparison with steep concrete roofs.

Table 2: Minimum roof live load of concrete roof slabs (Loads on Buildings and Structures, 2013)

\begin{tabular}{|c|c|c|c|}
\hline \multicolumn{2}{|c|}{ Type and Slope of Roof } & \multirow{2}{*}{$\begin{array}{l}\text { Distributed } \\
\text { Load, } \mathrm{kN} / \mathrm{m}^{2} \\
1.5\end{array}$} & \multirow{2}{*}{$\begin{array}{l}\text { Concentrated } \\
\text { Load, kN } \\
1.8\end{array}$} \\
\hline I & Flat roof (slope $=0)$ & & \\
\hline II & $\begin{array}{l}\text { 1. Pitched or sloped roof }(0<\text { slope }<1 / 3) \\
2 \text { Arched roof or dome (rise }<1 / 8 \text { span) }\end{array}$ & 1.0 & 0.9 \\
\hline III & $\begin{array}{l}\text { 1. Pitched or sloped roof }(1 / 3 \leq \text { slope }<1.0) \\
\text { 2. Arched roof or dome }(1 / 8 \leq \text { rise }<3 / 8 \text { span })\end{array}$ & 0.8 & 0.9 \\
\hline IV & $\begin{array}{l}\text { 1. Pitched or sloped roof (slope } \geq 1.0 \text { ) } \\
\text { 2. Arched roof or dome (rise } \geq 3 / 8 \text { span) }\end{array}$ & 0.6 & 0.9 \\
\hline V & Greenhouse, and agriculture buildings & 0.5 & 0.9 \\
\hline VI & $\begin{array}{l}\text { Canopies and awnings, except those with } \\
\text { cloth covers }\end{array}$ & \multicolumn{2}{|c|}{$\begin{array}{l}\text { same as given in I through IV } \\
\text { above based on the type and } \\
\text { slope. }\end{array}$} \\
\hline \multicolumn{4}{|c|}{$\begin{array}{l}\text { Note : (1) Greater of this load and rain load as specified in Sec } 2.6 .3 \text { shall be taken as the design live load } \\
\text { for roof. The distributed load shall be applied over the area of the roof projected upon a horizontal plane } \\
\text { and shall not be applied simultaneously with the concentrated load. The concentrated load shall be } \\
\text { assumed to act upon a } 300 \mathrm{~mm} \times 300 \mathrm{~mm} \text { area and need not be considered for roofs capable of laterally } \\
\text { distributing the load, e.g. reinforced concrete slabs. }\end{array}$} \\
\hline
\end{tabular}

Skylights that are placed on roofs to give natural light can pose a threat to roofers if too much weight is placed on these structures. A roofer can accidentally step on the skylight or even trip on the 
edges causing the roofer to fall off the roof (Morton, 2015). The height of parapet walls also poses a threat to roofers as buildings that are not provided with a barrier on the roof ledge can pose a great risk. This is because shortened walls can cause the roofer to trip and fall (Morton, 2015).

Regardless of the design of the roof, a cool roof which is a roofing system that possesses the ability to reflect ultraviolet wavelengths from the sun to reduce the amount of heat that is transferred to the building (Certain Teed, 2016), can cause extreme heat conditions for roofers. This can cause the roofer doing the repairs or renovations to become more tired and be susceptible to dehydration and unconsciousness when repairing the roof for long periods of time throughout the day (Morton, 2015). The chemicals that roofers are exposed to while roofing can become hazardous when breathing in the various toxins including lead and asbestos. In addition, these toxins can possibly blend with the rodent and bird feces that are stuck in the roof grooves, posing a biological threat (Morton, 2015).

Roofers who cut corners when carrying out their duties can pose a prodigious threat for themselves. For example, roofs that have multiple decks can cause workers to jump from heights that are not that high, especially if not enough ladders are available. This is dangerous for roofers as excessive jumping can cause them to fall off the roof (Morton, 2015). Besides, some materials that are used for roofing can be slippery for roofers to walk on such as metals (Theile, 2017) or as previously mentioned, fragile such as slate. Overall, cheap roofing materials have more deterioration tendency (Types of Roof Shingles, n.d). Roof shingles covered with loose surface are not suitable for a safe access. For example, asphalt shingles are covered with granules and this can cause the roofers to lose their balance while walking or stepping and trip or fall of the roof. The risk of fall increases with steep, high, wet or snowy asphalt roofs (Roof Safety \& Roof Fragility, 2016).

\section{Section 7: Tools Roofers Use to Reach Roofs}


Accessing roofs is a risky job that requires roofers to be aware that while transitioning from their lifting tool to the surface of the roof can cause them to fall. There are a number of available tools that roofers have to be careful while using in order to prevent those falls. These tools include a aerial lifts such as boom lifts and scissor lifts (Medsafe, 2017a). Since ladders are used for climbing (OSHA Quick Card, 2006), they will be further discussed along with the two areal lifts (boom and scissors lifts). Figure 14 below, shows how they look.

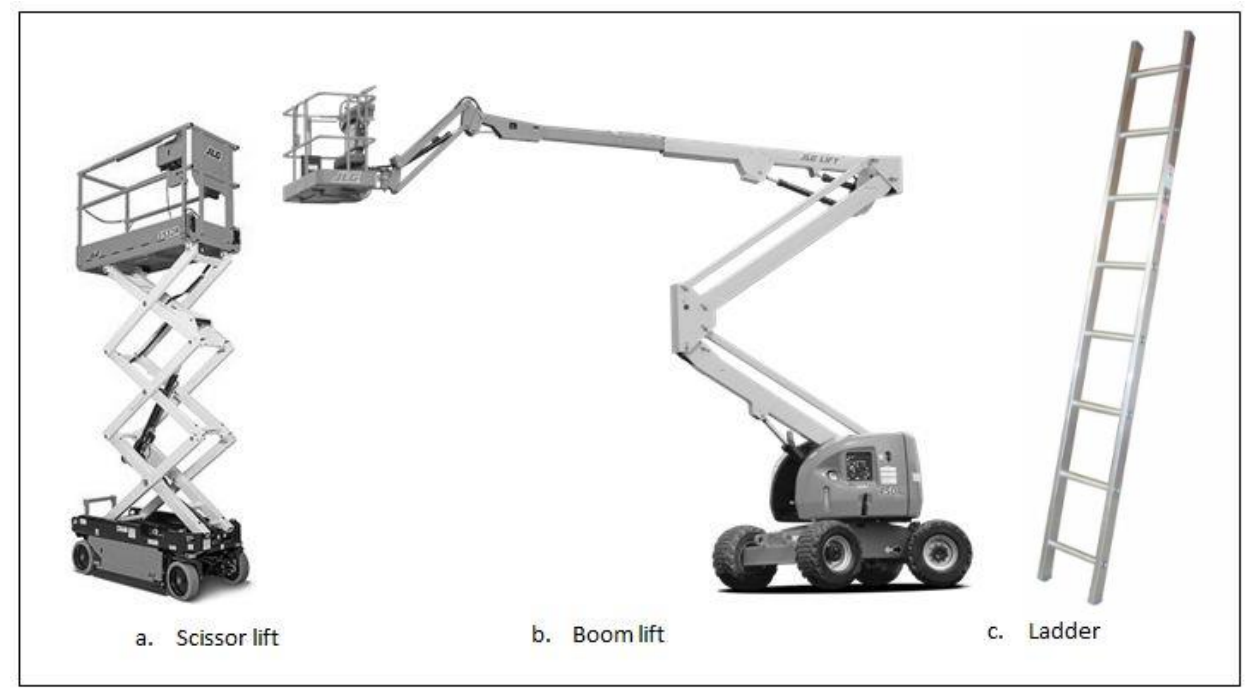

Figure 14: Tools Construction Workers Use to Reach Roofs (Prosrent, n.d; Metallic Ladder, n.d)

\section{Section 7a: Scissor Lift}

Scissor lifts (Figure 14a) are able to elevate roofers to high areas. These lifts are supported by braces that crisscross each other and extend upwards. Scissor lifts were designed to only move in an up and downward direction but there are scissor lifts that are able to move horizontally as well. One of the ultimate advantages of scissor lifts is that they possess a large platform compared to other areal lifts. This allows them to move many people at the same time including the materials (CTD, 2017). Therefore, they beneficial for roofing jobs that require accessing roof surfaces and carry building materials. 
However, scissor lifts can only reach low lift heights of about 20-50 feet, which is less than most of the available boom lifts. Scissor lifts also provide limited mobility as most of them are structured to move in one direction vertically and cannot move around various obstacles (CTD, 2017).

\section{Section 7b: Boom Lift}

Boom lifts (Figure 14b) share the same characteristics as aerial lifts and are more flexible than scissor lifts. The reason for this added advantage is that boom lifts possess a hydraulic arm that allows them to move around obstacles (CTD, 2017). There are two types of boom lifts, namely articulating boom lifts which possess arms that are able to bend, thus allowing the bucket to easily move around things, and telescoping boom lifts which possess straight arms; have higher weight capacities; and are difficult to move (CTD, 2017). Boom lifts vary in their reaching heights. A type is found to reach a maximum height of 186 feet and 90 feet for another type horizontally (Genie, 2018). This is an indication that they extend to greater heights than that of scissor lifts. The downfall is that boom lifts provide a smaller platform than scissor lifts and can only hold a limited number of workers and amounts of materials. Boom lifts are also more expensive than scissor lifts (CTD, 2017).

For both boom and scissors lifts, since falling from their baskets/buckets is a fall and death cause (Elcosh, 2001), OSHA lists a number of safety rules while/prior operation (OSHA510, Page 261, 2017). These rules include: testing the lifts daily, never tying off to objects outside the baskets, harness and lanyard application, feet be on the floor of baskets, not moving the lifts while baskets are elevated among others (OSHA510 Page 261, 2017). Aerial lifts are not to be positioned on uneven places and driven into holes. Operating them in rainy or snowy or low visibility conditions can cause slips and falls. Hiring inexperienced and/or untrained personnel before operation increases falling chances (Roofing contractor, 2003). 


\section{Section 7c: Ladder}

Ladders (Figure 14c) are popular tools people use to reach high areas. There are also many advantages and disadvantages associated with ladders (Mcfater, 2018). The safe maximum height that anyone can reach is about 4 feet higher than the height of the ladder e.g. a person can reach an 8-foot ceiling using a ladder that is 4 feet high (Werner, 2018). Facing the ladder as well as having three contact points are required while climbing or descending. Ladders must extend $3 \mathrm{ft}$. above the landing surface and to be set at an angle of (4ft vertical:1 ft horizontal). For stepladders, the top two steps have to be avoided and while the four top rungs have to be avoided for other ladders (Falls, PPT). As of 2005, the longest ladder was created (135 feet long) in Australia (Guinness World Records, 2015).

Ladders also have their disadvantages. They provide small or thin steps for workers to balance on, which increases the risk of slipping. They do not have a dedicated platform, which means that workers have to attach their equipment to their bodies (Mcfater, 2018). According to OSHA, workers are prevented from standing on the top three of straight, single or extension ladders'steps/rungs (OSHA Quick Card, 2006). This minimizes and limits workers' access. Also, there are usually no safety rails or guards on ladders, therefore this increase the risk of falling off the ladder (Mcfater, 2018). Table 3 below provides a summary of the three earlier discussed tools that construction workers use to reach roofs reflecting on the advantages and disadvantages.

Table 3: Summary of the differences between the tool's construction workers use to reach roofs

\begin{tabular}{|c|c|c|c|}
\hline & Scissor & Boom & Ladder \\
\hline Platform & Large & Small & Very small \\
\hline Able to reach low or high heights & Lower than boom & Highest & Lower than boom \\
\hline
\end{tabular}




\section{Section 8: Personal Fall Arrest Systems (PFAS) Used by Roofers}

Personal fall arrest systems (PFAS) were created and designed in such a way as to stop a worker from falling to the lower level of a structure in a safe manner (Protecting Roofing Workers, 2015). According to the OSHA, there are three components that have to be assured while having PFAS for roofers namely:

A. An anchorage which secures the roofer to the roof and is used to attach or connect the snap hook of the lanyard e.g. Angel anchor system and CB-12 anchor point (Protecting Roofing Workers, 2015)

B. A full body harness that is worn and holds the body of the worker to protect the worker from falls, e.g. Thunder safety harness (Protecting Roofing Workers, 2015).

C. A connector device, which includes a lanyard or lifeline that is used to link the harness to the anchorage device e.g. shock absorbing lanyard and retractable life line (Protecting Roofing Workers, 2015). 


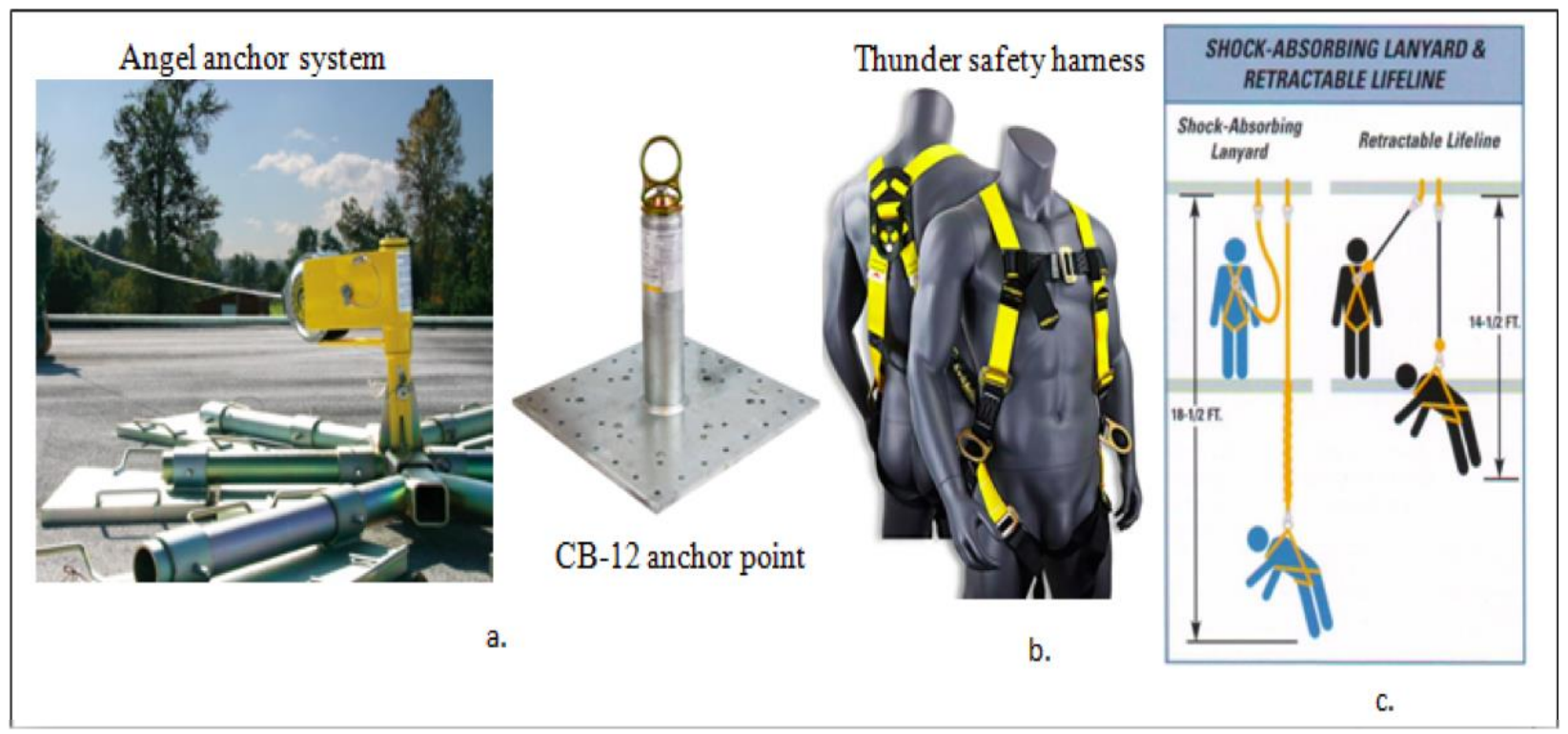

Figure 15: Three PFAS tools (Amazon, n.d, Falls protection pros, 2018b; Guardian fall protection, 2018; PK Safety, 2010)

\section{Section 8a: Angel Anchor System and CB-12 Anchor Point}

The Angel anchor system (figure 15a) meets all OSHA standards only if it is used according to the attached instructions that it comes with. In Fall Arrest applications, the structure in which the anchor is placed on should have the ability to withstand a load of at least 5000lbs or a minimum of 2:1 safety factor addressed by the qualified person (has training degree or certified) (Guardian fall protection, n.da). It has to be used by persons that possess a combined weight that ranges from 130-420 lbs. This weight includes tools, clothing, etc. Only one person is permitted to be connected to the anchor point per usage. PFAS that is used with the Angel anchor system needs to be assembled to limit the roofer from a freefall that is $6 \mathrm{ft}$. (Guardian fall protection, n.d-a). It is easy to install, made of galvanized steel and weighs 690 lbs. It also can be placed on a variety of surface types and consists of a "3-piece spine". The anchor can only be used on surfaces that are positioned up to a 5 degree angle, and does not require any penetration of the substrate (Guardian fall protection, n.d-b). This device minimizes the risk of 
swing falls as it comes with a detailed chart (Figure 16 below) that shows the allowable working distances on the roofs. This device has to be inspected prior to each usage. It has to be carefully checked of any possible deficiency including: missing labels, rough surfaces' exposure, cracking, corrosion, buildup paint, among others. It has to be cleaned from contaminants prior and after each usage. For storage, it should be away from heat, light, corrosives, chemicals or any hazards material (Guardian fall protection, n.d-a).

\begin{tabular}{|c|c|c|}
\hline $\begin{array}{l}\text { Anchor Distance } \\
\text { From } \\
\text { Leading Edge }(Y)\end{array}$ & $\begin{array}{l}\text { Working Distance } \\
\text { Along Roof Edge } \\
\text { (Either Direction) (x) }\end{array}$ & $\begin{array}{l}\text { Working Angle } \\
\text { From } \\
\text { Perpendicular (ø) }\end{array}$ \\
\hline $6^{\prime}$ & $8^{\prime}$ & $53^{\circ}$ \\
\hline $10^{\prime}$ & $9^{\prime}-9^{\prime \prime}$ & $45^{\circ}$ \\
\hline $15^{\prime}$ & $11^{\prime}-7^{\prime \prime}$ & $38^{\circ}$ \\
\hline $20^{\prime}$ & $13^{\prime}-3^{\prime \prime}$ & $33^{\circ}$ \\
\hline $25^{\prime}$ & $14^{\prime}-6^{\prime \prime}$ & $30^{\circ}$ \\
\hline $30^{\prime}$ & $16^{\prime}$ & $28^{\circ}$ \\
\hline $35^{\prime}$ & $17^{\prime}-2^{\prime \prime}$ & $26^{\circ}$ \\
\hline $40^{\prime}$ & $18^{\prime}-3^{\prime \prime}$ & $24^{\circ}$ \\
\hline $45^{\prime}$ & $19^{\prime}-4^{\prime \prime}$ & $23^{\circ}$ \\
\hline $50^{\prime}$ & $19^{\prime}-10^{\prime \prime}$ & $21^{\circ}$ \\
\hline $55^{\prime}$ & $21^{\prime}-4^{\prime \prime}$ & $21^{\circ}$ \\
\hline $60^{\prime}$ & $22^{\prime}-3^{\prime \prime}$ & $21^{\circ}$ \\
\hline
\end{tabular}

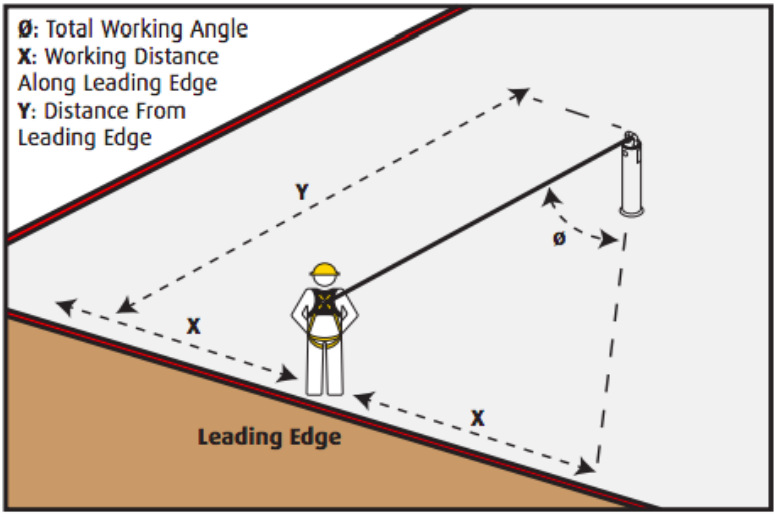

For example, if the anchorage connector is $6^{\prime}$ from the leading edge $(Y)$, the working distance $(X)$ is $8^{\prime}$ in each direction from the perpendicular, which translates to a $53^{\circ}$ working angle.

Figure 16: Allowable distances roofers can have by using Angel anchors.

The CB-12 anchor point (figure 15a) is another anchorage that also follows OSHA standards of fall protection and can be placed on substrates which include wood, steel and concrete, is compatible with horizontal lifelines as well as vertical lifelines and lanyards, easy to install, weighs 35lbs (Guardian fall protection, n.d-c), requires penetration to the substrate, can be used in harsh weather conditions, and is cheaper than the angel anchor system (Fall protection pros, 2018a). The same allowable distances instruction (Figure 16 above) that comes with Angel anchor points to avoid swing falls is also attached to CB-12 anchors. CB-12 anchor has a minimum breaking strength of 5000lbs, maximum freefall limits 
of 6. and made of galvanized steel as well (Guardian fall protection, n.d-c). For installation, the minimum required thickness of the substrates (wood, metal, concrete) differs from one another. Besides, penetration depth also changes (Figure 17).

\section{Wood Install:}

MINIMUM substrate requirement: $5 / 8^{\prime \prime}$ thick CDX.

1. Place $C B-12$ at selected installation location.

2. Install all (40) fasteners until snug, and ensure CB-12 is fully secured to substrate.

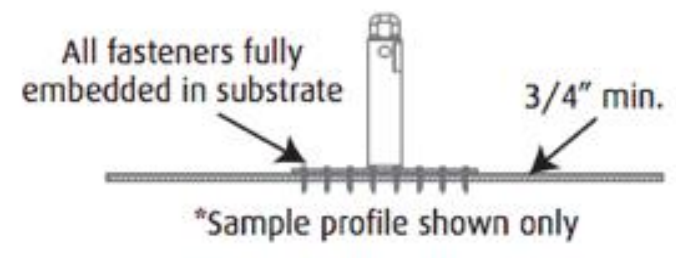

3. All fasteners MUST be fully embedded in wood decking.

\section{Metal Install:}

MINIMUM substrate requirement: 20 gauge, or 22 gauge if reinforced with CB Spanner Plate (part \# 00604, contact Guardian for more information).

1. Place CB-12 at selected installation location.

2. Install all (40) fasteners until snug, and ensure CB Anchor is fully secured to substrate.

3. All fasteners MUST penetrate metal decking by at least $1 / 4^{\prime \prime}$.

\section{Concrete Install:}

MINIMUM substrate requirement: 6 " thick, 2,500 psi.

Installation must be done a MINIMUM $8^{\prime \prime}$ from all fall hazards.

1. Place CB-12 at selected installation location.

2. Install all (8) fasteners until snug, and ensure CB-12 is fully secured to substrate.

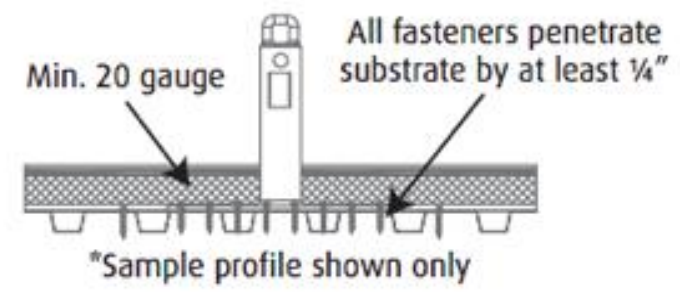

3. Always refer to fastener manufacturer's instructions regarding fastener installation.

Figure 17: CB-12 installation differences between wood, metal and concrete (Guardian fall protection, n.d-c) 
Although it is easy to assemble both devices, it is imperative that the user of the system is familiar with the instructions, is trained on how to use the devices and how to care for them, and is fully aware of how the devices operate, what the limits are and what the consequences are if not properly utilized. If these conditions are not followed through, the roofer can endure or sustain serious and even deathly injuries (Guardian fall protection, n.d-a, Guardian fall protection, n.d-c).

\section{Section 8b: Thunder Safety Harness}

This is a harness (figure 15b) follows OSHA standards and has load straps which are made of non-recycled fully synthetic fibers. The synthetic material is strong, can age long, is abrasion and is resistant to heat. The full body harness fits the worker comfortably as the shoulder and leg straps are snug, chest straps are aligned at the center of the chest; and the dorsal ring at the back of the harness is used for fall arrest as well as "restraint and rescue". In a falling situation, the pressure is directed through the straps of the shoulders and the area around the thighs which brings the roofer into an upright position slightly leaning to the front, resulting in a possible pressure on the lower chest. The user of the harness must have a weight range of 130lbs to 310lbs (Amazon, 2018).

The OSHA regulatory requirements have been incorporated into the manufacturing of the PFA systems. The security, positioning, all necessary tools and equipment are essential in the makeup of those systems as failure to do so can put the roofers' life in jeopardy. One example of those serious conditions is suspension trauma which means being hung or held in an upright position without moving for a period of time (Roofing Industry, 2017). Suspension trauma is found to be life threatening. When the worker falls in an upright position and not moving his/her legs, the gravity causes the blood to pool in the legs. This stops the blood from returning back to the heart. The heart speeds up and beats faster to supply enough blood to the brain. Another factor that increases the threat is the straps that can also place pressure on the leg veins of the worker which can 
negatively impact blood flow (Roofing Industry, 2017). In case the heart fails to supply enough blood to the brain, unconsciousness starts to happen and gets followed by death (Weems et al., 2003).

\section{Section 8c: Shock absorbing lanyard and retractable life line}

During any fall arrest, the body needs a system that is able to minimize the amount of force that is created (free fall force). Shock absorbing lanyards (Figure 15c) are made for that purpose as they are

a PFAS that is featured with an extension ability. The device has been designed to keep the arresting forces applied to the body to a free fall force of $9001 \mathrm{bs}$ or anything less than this amount. They are mostly available in any length up to $6 \mathrm{ft}$. with a combination of hooks at the start and end points. The maximum allowable body weight attached to the lanyard is $310 \mathrm{lbs}$. Inspection is required prior to each use (Simplified safety, 2013).

To avoid the contact with the ground during a free fall using shock absorbing lanyard, it is essential to calculate the potential fall distance (Safety Equipment FAQ, 2015). The diagram below shows the total distance from the anchorage that the lanyard is connected to the ground. The calculation includes the standard length of the lanyard, deceleration distance, average height of the worker and the potential safety factor. 


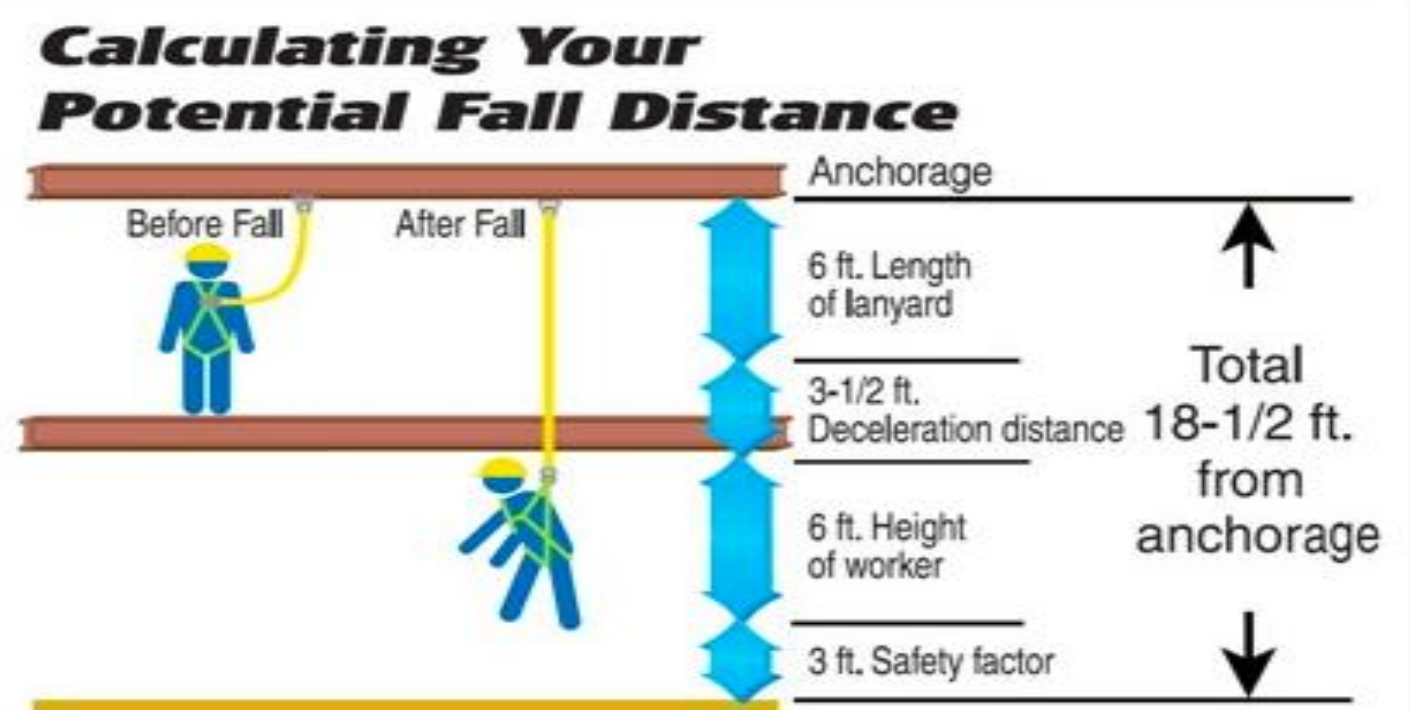

Figure 18: Calculating the potential falling distance using shock absorbing lanyard (Falls, PPT)

There are a number of shock absorbing lanyards. Depending on the needs they are selected (Simplified safety, 2013), As of 1998, the use of shock absorbing lanyard is not mandatory (Sawnson, 1998). Therefore, self-retracting life lines come as another option.

A self-retracting life line (SRL) (Figure 15c) or a self-retracting lanyard is a part of the PFAS that have a retractable line within a case that functions like a seat belt when activated (Simplified safety, 2015). This system is designed to stop free falls immediately. It is made to be positioned above the worker's head and mostly gets attached to the safety harness back's dorsal ring (Simplified safety, n.d). SRL's were not initially the preferred PFAS of choice by workers not for its functionality but because they initially had a bulky design that were too heavy for workers. However, as technology improved, many SRL's have now been designed to weigh much lighter and are more portable (Simplified safety, 2015). The way this system works is that during a free fall, when the body reaches a certain level of falling's speed, a braking and a locking mechanism get engaged to prevent the fall (Simplified safety, 2015) (Simplified safety, n.d). 
The way the SRL works is simple, it is held by hand, slowly the cable or the webbing is taken out to the desired length. The retraction starts when the cable is released, however, if it is pulled hard, the system immediately locks and stops any further extension to the cable (Simplified safety, 2015). In terms of the length the cable can extend to, that depends on buyer's choice as there are various designs and configurations with different extension lengths (3M, n.d). Most advanced SRL types nowadays range in length from 6 to $200 \mathrm{ft}$. (Capital Safety, 2015). All SRLs have to meet OSHA requirements. They are designed for a single user with a capacity of maximum 310lbs to 400lbs including tools, clothes, etc. (3M, 2012). Figure 19 below, shows the free fall distance that SRLs should have.

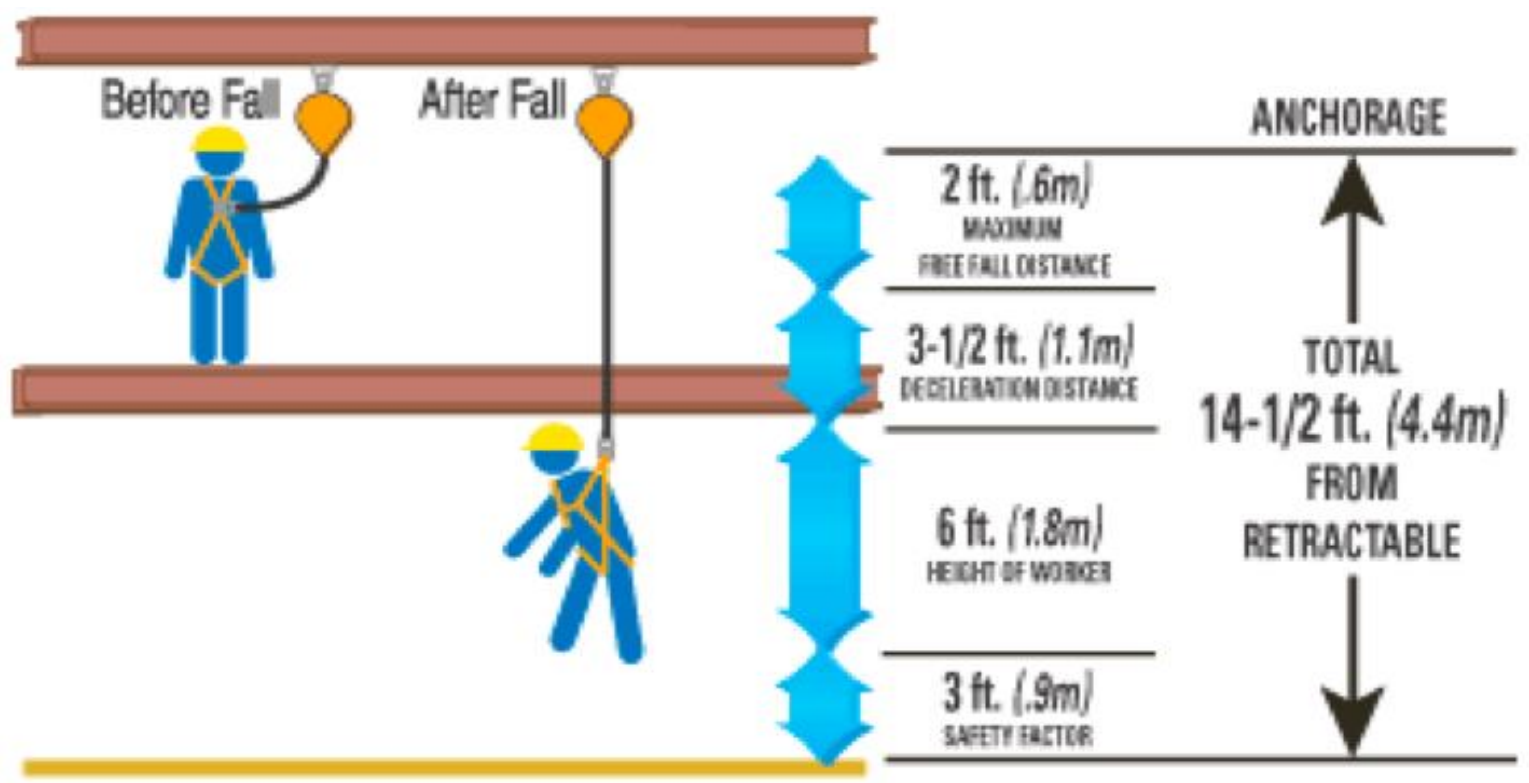

Figure 19: Calculating the free fall clearance distance using SRLs (Falls, PPT)

\section{Note:}

- According to OSHA, for all PFASs, the maximum weight capacity of the worker is $310 \mathrm{lbs}$ including tools, clothes, etc. Any employee that exceeds $310 \mathrm{lbs}$, there should be a 
special modification with a specific criteria and protocol on the PFAS in order for it to be safely used (Medsafe, 2017b).

- No matter what anchorage connecter is used, OSHA limits free fall distance to $6 \mathrm{ft}$. (Protecting Roofing Workers, 2015).

- No matter what anchorage connecter is used, the freefalls maximum force should be limited to 1800lbs (Medsafe, 2017b).

\section{Section 9: Organizations}

\section{Section 9a: OSHA}

Is the Occupation Safety and Health Administration that has a mission and a mandate to generate regulations for employers to provide safe working conditions for their employees and creates standards, training and other tools such as education, advice and more to achieve this mission (Protecting Roofing Workers, 2015). Among the years 1994, 1995, 2001, 2010 and 2014 (figure 20 below), OSHA made several updates to roofing security elements and fall protection standards. As technology is developing, so is the equipment. With respect to ladders, some of updates were made in the years 1991 and 2014 (Stairways and Ladders, 2018). Having a considerably big time period between the updates made to the fall protection standards can result in some confusion between the users of new equipment that have uncommon specifications, or that combine elements of two different categories. For example, as shown in figure 13 below, scissor loft stairs, although not an aerial vehicle, has a few characteristics of scissor lifts and is a major aspect of regular ladders. As a result, potential confusion might arise while categorizing such kind of advanced equipment. 


\section{Systems to proteci empivyees II " Iе aica.}

Work area means that portion of a walking/working surface where job duties are being performed.

[59 FR 40730, Aug. 9, 1994, as amended at 60 FR 39255, Aug. 2, 1995; 66 FR 5265, Jan. 18, 2001; 75 FR 48133, Aug. 9, 2010; 79 FR 20696, Apr. 11, 2014]

\section{8}

Figure 20: Some updates on roofing and fall protection rules between 1994 and 2014 (OSHA Manual Page 338, 2018)

The main goal expected by these updates is to ensure that injuries that take place in the workplace, sicknesses, and deaths are not only limited but prevented. The practices recommended for this make use of proactive methods that could manage the safety and health of many workers in the workplace (Safe Workplace, 2017). Traditional approaches have proved that issues were only addressed once workers were injured or fallen, and only then a new regulation was applied. Therefore, these recommended practices would aim at identifying and correcting these issues and hazards before they take place and should be initiated by setting precise rules (Safe Workplace, 2017). The upgraded standards of OSHA are obtained in coordination with other agencies' field research findings such as the National Institute for Occupational Safety and Health (NIOSH).

\section{Section 9b: NIOSH}

The federal agency known as the "National Institute for Occupational Safety and Health (NIOSH) (NIOSH Hazard Evaluation, 2005) is an agency of the United States Department of Health and Human Services, that is involved in conducting research on a scientific and medical platform which 
include working conditions that are hazardous, diseases in the workplace, any types of injuries and disabilities occurring in the workplace, and education for ensuring the safety and health of workers (NIOSH Hazard Evaluation, 2005). Without incurring any costs to employers or workers involved, NIOSH is able to recognize potential health hazards that take place in the workplace and regulate ways in which it can reduce or prevent these hazards from taking place. This is done through its "Health Hazard Evaluation (HHE) Program (NIOSH Hazard Evaluation, 2005).

The main objectives of NIOSH include (1) conducting effective research platforms that would decrease the probability for injuries and sicknesses to occur in the workplace thereby enhancing the wellbeing of workers, and (2) developing solutions to issues that are not easy to solve especially in industrial sectors that have been labeled as high risk (CDC, 2017). NIOSH also aims at promoting the safety and health of workers in the workplace by providing a platform for various interventions as well as recommendations that would be able to enhance its relevance. Finally, it transfers the findings obtained by research and technologies into practices, and ensures that the capacity is there to identify and address the various hazards that take place (CDC, 2017).

NIOSH acknowledges that edges and other hazards such as roof holes and areas for skylight structures are common for the high numbers of roofer injuries and deaths. NIOSH suggests the introduction of a patent design involving roof brackets that are adjustable and allows roofers to work on level wooden boards while being on steep roofs (Bobick et al., 2006). In 2003, NIOSH along with other roofing and asphalt associations have published a detailed document under the title of "Asphalt Fume Exposure During the Application of Hot Asphalt to Roofs". As mentioned in the introduction, asphalt fumes are associated with health risks. According to the document, no OSHA existing standard is available for asphalt fumes (Asphalt Fume Exposure, 2003). However, with the help of NIOSH and 
other associations, roofers can step-by-step minimize the spread of fumes while applying asphalt at rooftops such as working upwind as much as possible. Hot asphalt containers such as hot luggers, buckets, mop carts and others have to be filled or refilled upwind as well. These containers should remain closed at all times with the exception of refilling operation time. The buckets should be maximum threefourths full and must have a half lid to reduce spillage. As well, the use of external fan is recommended to circulate away asphalt fumes (Asphalt Fume Exposure, 2003). With all these instructions, fatigue and unconsciousness caused by asphalt fumes is highly diminished, and therefore, less falling accidents is expected to happen.

\section{Section 10: Recommendations}

It is the duty of the employer to take the necessary steps to protect roofers. These protection strategies include limiting the number of people allowed to access the roof, providing efficient training for the individuals who are allowed to access the roof, and offering the right safety equipment to help reduce these risks and protect contractors from potential harm (Morton, 2015). Given the fact that roofers are exposed to fatal and non-fatal injuries, roofing employers need to ensure that roofers are given the appropriate training regarding fall protection so that they are well-informed about all the various forms of fall protection available to ensure safety working conditions (OSHA Fact Sheet, 2011).

For roofing's PFAS, OSHA does not limit roofers with only one or two options. Depending on the roof's steepness, there are more than one allowable option to protect roofers from falling hazards. for low-slope roofs, roofers can be protected by setting warning-line systems at a distance of $6 \mathrm{ft}$. from the edges, once the warning-lines are placed, a combination of another fall-protection system is required (e.g. safety-monitoring system), however, if the roofs width is $50 \mathrm{ft}$. or less, having a safety-monitoring system alone is allowable (Protecting Roofing Workers, 2015). For unprotected edges and sides of steep- 
slope roofs, roofers must use a protection system at a $6 \mathrm{ft}$. distance from the lower level. The protection system includes either guardrail systems with toe boards, a safety-net system, or a PFA system (Protecting Roofing Workers, 2015). Here are some overall recommendations for this research:

- The freedom of choosing the roof type and roofing materials to cover the roof with should be assured.

- Owners of building/houses should be responsible of the consequences after choosing both roof type and roofing materials.

- Where areas experience only rain falls, the need of having highly pitched roof could be avoided. Steep-slope roofs are more hazardous to roofers than low-sloped roofs. Also, steepsloped roofs limit the buildings' inner space.

- Roofing lifting tools differ in their maximum reaching points. Statistics showed ladders are the highest leading cause of deaths after roofing. Three points of contact, facing the ladder while escalating/descending, and 4:1 ladder position's angle are some of requirements when using ladders.

- Anchors (e.g Angel or CB-12) have to be able to withstand a minimum force of 5000lbs or have a minimum safety factor of $2: 1$.

- Shock absorbing lifelines (SAL) and Self retracting lanyard (SRL) differ in their lengths and free fall safe distances. Therefore, depending on the need of a project, length of the SAL and SRL should be chosen.

- Roofers facing suspension trauma situations caused after a free fall should be given more attention as each one's ability to fight the lack of blood supply differ. They should be either released of pulled up immediately. 
- Some OSHA regulations might not be up-to-date, but they must be followed and the project must be in compliance of safety requirements.

- NIOSH conducted field research and this study show that there are gaps in the safety management tools and its implementation. To fill those gaps, NIOSH developed specific safety tools and procedures such as adjustable roofing brackets. These provide additional protection and have to be used in construction projects.

The protection system not only saves roofers lives at roofs but also saves contractors' money from receiving citations. A case was reported on OSHA's website where a roofing company was fined in the amount of $\$ 52,800$. The company continuously exposed its roofers to fall hazards by allowing them to work and install shingles on steep roofs using no fall protection. OSHA insists that providing necessary protection is the company's responsibility and failure to do so is unacceptable (Allen \& Burke, 2014).

\section{Section 11: Conclusion}

Roofs are a landmine for many roofers. There are still many flaws in the roofing practices, which could be improved by the various attributes of the organizations involved in the safety of these worker, thereby providing roofers with a more peace of mind in terms of their safety and well-being. The rate of non-fatal fall injuries and deaths have remained relatively high over the past years. This could have been possibly reduced if the organizations involved in the health and safety of these workers (e.g., OSHA \& NIOSH) enforced stronger laws and regulations that were in favor of roofers. Employers should ensure that roofers are provided with the appropriate safety training, particularly fall safety. The materials provided in roofing practices as well as the types of 
roofs all play an essential role in the safety of roofers and sufficient training and precautions should be implemented in order to ensure the safety of workers. Roofing is an integral service provided to millions of people worldwide. By following and improving the current safety regulations and guidelines, this imperative occupation can potentially become safer to roofers who endanger their lives every day to perform their jobs. 


\section{References}

3M (n.d), Self-retracting lifelines. $3 m$ web. Retrieved from

https://www.3m.com/3M/en US/company-us/all-3m-products/ /All-3M-

Products/Safety/Worker-Health-Safety/Personal-Protective-Equipment/Fall-Protection/Self-

$\underline{\text { Retracting- }}$

$\underline{\text { Lifelines/?N }=5002385+8709322+8711017+8711405+8720539+8720544+8735084+3294857497}$

$\underline{\mathrm{krt}=\mathrm{r} 3}$

3M (2012), 3M occupational health and environmental safety. Media distributor data solutions web.

Retrieved from

https://media.distributordatasolutions.com/3M/3MOilGas/files/File 4668 3M Self Retractin

g_Lanyards UI.pdf

Amazon (n.d), Kwik safety (Charlotte, NC) Thunder safety harness. Amazon web. Retrieved from https://www.amazon.com/KwikSafety-Protection-Protective-ConstructionIndustrial/dp/B018RLPEY0

Big Al (2017), Top 15 roof types, plus their pros \& Cons - Read before you build. Roof cost estimator web. Retrieved from https://www.roofcostestimator.com/top-15-roof-types-and-their-proscons/

BLS (2018), National census of fatal occupational injuries in 2016. Bls web. Retrieved from https://www.bls.gov/news.release/archives/cfoi 12192017.pdf 
Bobick, T.G., Cantis, D.M. \& McKenzie, E. (2006), NORA Symposium 2006: Research Makes a Difference! April 18-26, 2006, Washington, DC. National Institute for Occupational Safety and Health, 141-142. Retrieved from https://www.cdc.gov/niosh/nioshtic-2/20030149.html

Bureau of Labor Statistics (2018), Roofers. Bls web. Retrieved from https://www.bls.gov/ooh/construction-and-extraction/roofers.htm

Cable News Network (2010), America’s 10 most dangerous jobs. CNN web. Retrieved from https://money.cnn.com/galleries/2010/pf/1008/gallery.most dangerous jobs/6.html

Centers for Disease Control and Prevention "CDC” (2011), Morbidity and mortality weekly report (MMWR). CDC web. Retrieved from https://www.cdc.gov/mmwr/preview/mmwrhtml/mm6316a2.htm

CDC (2017), NIOSH healthcare and social assistance program. CDC web. Retrieved from https://www.cdc.gov/niosh/programs/review/pdfs/NIOSH HCSA Program Review Panel Report Oct 2017-508.pdf

Capital Safety (2015), Product search. Capital safety web. Retrieved from https://www.capitalsafety.com/bradmin/Pages/Search.aspx?prodCatId $=5 \# 0$

Certain Teed (2016), What is a cool roof, Certain Teed web. Retrieved from https://www.certainteed.com/residential-roofing-commercial-roofing/what-cool-roof-0/

Coe, E. (2017, February), Asphalt Roofing: The Pros and Cons. Quotatis web. Retrieved from http://roofing.quotatis.co.uk/asphalt-roofing-pros-cons/ 
Common Stats (2017), Commonly used statistics, U.S. Department of Labor Occupational Safety and Health Administration. Osha web. Retrieved from https://www.osha.gov/oshstats/commonstats.html

Construction focus four (2011), fall hazards, instruction guide. OSHA Training Institute. Osha web. Retrieved from https://www.osha.gov/dte/outreach/construction/focus four/falls/falls ig.pdf

The Center for Construction Research and Training "CPWR” (2013), Fatal and Nonfatal Injuries from Falls in Construction. Stop construction falls. Retrieved from https://stopconstructionfalls.com/wp-content/uploads/2013/07/Fatal-and-Nonfatal-Injuriesfrom-Falls-in-Construction-2013-update.pdf

CTD (2017), Scissor lifts vs Boom lifts. Retrieved from http://www.c2cequip.com/scissor-lifts-vs$\underline{\text { boom-lifts } /}$

Des (2017), Design build best practices guidelines. Des web. Retrieved from https://des.wa.gov/sites/default/files/public/documents/About/CPARB/2017Meetings/11Nov/12a-DBBP-Guidelines Draft.pdf

Desmesne (2018), What's on your roof? Desmesne web. Retrieved from http://www.demesne.info/Improve-Your-Home/Roofing.htm

Elcosh (2001), Deaths from aerial lifts, Elcosh web. Retrieved from http://www.elcosh.org/document/1417/d000484/Deaths+From+Aerial+Lifts.html?show tex $\underline{\mathrm{t}=1}$ 
Elcosh (2017), Causes of roofer deaths. Elcosh web. Retrieved from

http://elcosh.org/document/1428/d000491/causes-of-roofer-deaths.html

Fall protection pros (2018a), CB-12 roof anchor. Fall protection falls web. Retrieved from https://www.fallprotectionpros.com/products/guardian-cb-12-roof-anchor

Fall protection pros (2018b), Guardian angel anchor point. Fall protection falls web. Retrieved from https://www.fallprotectionpros.com/products/guardian-angel-anchor-system

Falls PPT, Occupational Safety and Health Administration. Retrieved from https://www.osha.gov/dte/grant materials/fy09/sh-19504-09/falls.pptx

Fountaine, S. (2017), Roof inspections: checklist and information. Buildings web. Retrieved from https://www.buildings.com/buzz/buildings-buzz/entryid/278/roof-inspections-checklist-andinformation

Genie (2018), Telescopic Boom Lift. Genie lift web. Retrieved from https://www.genielift.com/en/aerial-lift/telescopic-boom-lifts

Guardian fall protection (2018), CB-12 anchor point. Guardian fall web. Retrieved from https://www.guardianfall.com/performance-safety-products/product/cb-12-anchor-point

Guardian fall protection (n.d-a), Product name: Angel anchor. Shopify web. Retrieved from https://cdn.shopify.com/s/files/1/2519/5508/files/guardian-angel-anchor-manual.pdf Guardian fall protection (n.d-b), Angel anchor system. Gaurdian fall web. Retrieved from https://www.guardianfall.com/performance-safety-products/product/angel-anchor-system 
Guardian fall protection (n.d-c), CB-12 anchor point. Gaurdian fall web. Retrieved from https://www.guardianfall.com/index.php?option=com hikashop\&ctrl=product\&task=show\&

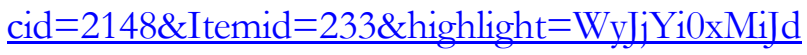

Guinness World Records (2015), Longest ladder, Guiness world records web. Retrieved from http://www.guinnessworldrecords.com/world-records/longest-ladder

How Slope Your Roof Determines (n.d), Residential Roofing Commercial Roofing, Certain Teed Web. Retrieved from https://www.certainteed.com/residential-roofing-commercial-roofing/how-slope-your-roofdetermines-your-roofing-material-options/

Interpretations and Clarifications (1995), Subpart M -- FALL PROTECTION, Oshaweb. retrieved from HTTPS://WWW.OSHA.GOV/PUBLICATIONS/CONST_RES_MAN/1926M_INTERPS.HTML

Jones, K. (2016), What are the deadliest jobs in construction. Retrieved from https://www.constructconnect.com/blog/construction-safety/deadliest-jobs-construction/

Krow (n.d), The Disadvantages of Asphalt, Hunker web, Retrieved from https://www.hunker.com/12546353/the-disadvantages-of-asphalt

Kumar, P. (2010), Injuries due to fall from height: a retrospective study. Journal of Forensic Medicine and Toxicology, 27(1), 47-49. Retrieved from https://www.researchgate.net/publication/280316149 INJURIES DUE TO FALL FROM HEIGHT - A RETROSPECTIVE STUDY

Loads on Buildings and Structures (2013), Chapter 2, Law Resource web, Retrieved from HTTPS://LAW.RESOURCE.ORG/PUB/BD/BNBC.2012/GOV.BD.BNBC.2012.06.02.PD $\underline{\mathrm{F}}$ 
Mcfater, J. (2018), Traditional ladders vs. work platforms. Levitt safety web. Retrieved from https://www.levitt-safety.com/blog/traditional-ladders-vs-work-platforms/

Medsafe (2017a), Fall Protection in Aerial Lifts: How to Comply with the OSHA Standards. Go safe web. Retrieved from http://blog.gosafe.com/fall-protection-in-aerial-lifts-how-to-comply-withthe-osha-standards

Medsafe (2017b), Big guys need fall protection too! How much weight can your harness support. Go safe web. Retrieved from http://blog.gosafe.com/big-guys-need-fall-protection-too-how-muchweight-can-your-harness-support

Metallic Ladder (n.d), Manhole Ladder - Type 1A, Metallic Ladder web. Retrieved from https://www.metallicladder.com/product/manhole-ladder-type-1a/

Moore, J.R. \& Wagner, J.P. (2014), Fatal events in residential roofing. Safety Science, 70, 262-269. Retrieved from https://www.sciencedirect.com/science/article/pii/S092575351400157X

Morton, J. (2015, February), Eliminate the risk of injuries with protection devices, ongoing training, and access policies. Buildings web. Retrieved from https://www.buildings.com/articledetails/articleid/18484/title/best-practices-for-roof-safety/viewall/true

Nelson \& Associates (2006), Five Types of Same-Level Falls, Fact Sheet on Hazard Control Web. Retrieved from http://www.hazardcontrol.com/factsheets/pdfs/five-types-of-same-level-falls.pdf NIOSH Hazard Evaluation (2005), Help For Employers, OSHA web. U.S. Department of Labor Occupational Safety and Health Administration. Retrieved from https://www.osha.gov/dcsp/compliance assistance/hhe program.html 
OSHA510 Page 261 (2017), Standard Course, Occupational Safety and Health Standards for Construction, New York Public Library Digital Collection.

OSHA Archive (2016), U.S. Department of Labor Occupational Safety and Health Administration, OSHA web. Retrieved from https://www.osha.gov/archive/oshinfo/priorities/asphalt.html

OSHA Fact Sheet (2011), Reducing falls during residential construction: roof repair. United States Department of Labor. OSHA web. Retrieved from https://www.osha.gov/Publications/reducing-falls-roof-repair-factsheet.html

OSHA Manual Page338 (2018), 29 CFR 1926 OSHA Construction Industry Regulations and Standards. Required By US Department of Labor. Copy Right (C MMII-MMXVII by Mancomm, Inc [315 W $4^{\text {th }}$ St. Davenport, IOWA 52801].

OSHA Quick Card (2006), Portal ladder safety. OSHA web. Retrieved from https://www.osha.gov/Publications/portable ladder qc.html

PK Safety (2010), What is a Selfretracting Lifeline? PK Safety web. Retrieved from https://pksafety.com/blog/what-is-an-srl

Prosrent (n.d), 26 Ft Scissor Lift \& Articulating Boom Lift - 35 ft

- Electric. Pros rent web. Retrieved from

https://www.prosrent.com/products/26-ft-scissor-lift-electric

$\&$

https://www.prosrent.com/products/35-ft-boom-lift-articulating 
Protecting Roofing Workers (2015), Occupational Safety and Health Administration (OSHA), 2015.U.S. Department of Labor Occupational Safety and Health Administration. OSHA web. Retrieved from https://www.osha.gov/Publications/OSHA3755.pdf

Rigid lifelines (2012), A brief history of fall protection. Rigid Life lines web. Retrieved from https://www.rigidlifelines.com/blog/entry/a-brief-history-of-fall-protection

Roof inspection checklist (2007), Assets Maintained and Operated by GNWT, Inf web. Retrieved from https://www.inf.gov.nt.ca/sites/inf/files/roof inspection checklist.pdf

Roofing contractor (2003), High on safety: Eliminating Aerial and Scissor Lift Accidents. Roofing Contractor web. Retrieved from https://www.roofingcontractor.com/articles/85076-high-on$\underline{\text { safety-eliminating-aerial-and-scissor-lift-accidents }}$

Roofing Industry (2017), U.S. Department of Labor Occupational Safety and Health Administration. . OSHA web. Retrieved from https://www.osha.gov/dte/grant materials/fy12/sh-2353612/StudentReferenceMaterials.pdf

Sadheghi H. \& Mohandes, S.R. (2013, October), The important role of different roof types in terms of energy performances within buildings: literature review. Research Gate web. Retrieved from https://www.researchgate.net/publication/271195903 THE IMPORTANCE ROLE OF D IFFERENT ROOF TYPES IN TERMS OF ENERGY PERFORMANCES WITHIN T HE BUILDINGS LITERATURE REVIEW

Safe Workplace (2017), Recommended practices for safety and health programs. United States Department of Labour. OSHA web. Retrieved from https://www.osha.gov/shpguidelines/ 
Safeopedia (n.d), Self-retracting lanyard (SRL), Safeopedia web. Retrieved from https://www.safeopedia.com/definition/1532/self-retracting-lanyard-srl

Safety Equipment FAQ (2015), Shock absorbing lanyard limitations. Safety Equipment FAQ web. Retrieved from http://safetyequipmentfaq.com/2014/01/19/shock-absorbing-lanyardlimitations/

Simplified safety (2015), How does a self-retracting lifeline work? Simplified safety web. Retrieved from https://simplifiedsafety.com/blog/how-does-a-self-retracting-lifeline-work/

Simplified safety (n.d), Self-retracting lifelines (SRL). Simplified safety web. Retrieved https://simplifiedsafety.com/fall-protection-lifelines/tie-off/retractable-lifelines/

Simplified safety (2013), A simple guide to shock packs and lanyards. Simplified safety web. Retrieved from https://simplifiedsafety.com/blog/a-simple-guide-to-shock-packs-lanyards/

Sawnson, R. (1998), Occupational health and safety administration. United States Department of Labor. OSHA web. Retrieved from https://www.osha.gov/lawsregs/standardinterpretations/1998-06-03

Stebbins, S., Comen, E., Stockdale, C. (2018, January), Wallst web. Retrieved from https://247wallst.com/special-report/2018/01/02/25-most-dangerous-jobs-in-america/6/

Theile (2017), The merits and drawbacks of metal roofs. The spruce web. Retrieved from https://www.thespruce.com/the-dangers-of-metal-roofing-1152472

Types of Roof Shingles (n.d), The Complete Guide, 918 constructionWeb, Retrieved from https://www.918construction.com/types-of-roof-shingles/ 
United Home Experts (2018), Pros and cons of rubber roofing. United home experts web. Retrieved from https://unitedhomeexperts.com/pros-and-cons-of-rubber-roofing/

Variant (2017), Commercial roofing materials market overview. Variant market research web. Retrieved from https://www.variantmarketresearch.com/report-categories/chemicalsmaterials/commercial-roofing-materials-market

Vross, A. (2012, April), Commercial roof maintenance: a proactive approach. Buildings web. Retrieved from https://www.buildings.com/news/industry-news/articleid/13887/title/commercial$\underline{\text { roof-maintenance-a-proactive-approach }}$

Weems, et al (2003), Suspension Trauma and Rescue Harness Safety, Fire Engineering web, Retrieved from

HTTPS://WWW.FIREENGINEERING.COM/ARTICLES/PRINT/VOLUME156/ISSUE-12/FEATURES/SUSPENSION-TRAUMA-AND-RESCUE-HARNESSSAFETY.HTML

Werner (2018), How to choose a ladder. Werner co web. Retrieved from https://www.wernerco.com/us/support/ladder-safety-tips/how-to-choose-a-ladder

Yellow Blue Tech (2014), Percentage of total sales by product type: Residential 2014. Yellow blue tech web. Retrieved from https://yellowbluetech.com/2016/05/04/attic-ventilation-productsincluding-solar-attic-fans-increase-roofing-sales/attic-ventilation-products/ 
Your Guide to Asphalt (2017), "What Are the Best Shingles for My Roof?, Tide water roofing web, Retrieved from

HTTPS://TIDEWATERROOFING.COM/YOUR-GUIDE-TO-ASPHALT-SHINGLES-

WHAT-TO-PUT-ON-YOUR-ROOF-HOW-LONG-THEYLL-LAST-ONCE-THEYRE-

ON-THER 